\title{
The Americanization of Film Subtitles: A Sociocultural Linguistic Perspective to Subtitling Translation in the Arab World
}

\author{
Muayyed J. Juma (PhD) Rafid Abdul-Ameer Ghaeb (PhD) \\ AL- Mamon University College
}

\begin{abstract}
:
The amount and diversity of mass media that our age witnesses have created a great deal of challenge to the process of translation all over the globe. As an autonomous discipline of translation, the audio visual translation (AVT) has been flourishing due to the thousands satellite channels which are in a continuous pursuit of new subtitled programs. Subtitling translation, accordingly, has exceeded its previous limited scope of films to include various types of reality TV shows, sport, documentaries, fashion programs etc. Consequently, the need for professional expert subtitlers has become one of the hallmarks of our modern age of globalization.

One inevitable technique used by translators is to draw the author's modes of thinking towards that of the reader as close as possible without paying much attention to the various aspects of meaning associated. This domestication technique has been criticized by Venuti (1995) for its denial of the visible role of the translator in his/her translated text. As a substitute, a translator might foreignize the reader's modes of thinking and introduce him to that of the author. In parallel, a film subtitler is doomed to choose one of these preferences either to satisfy the target language audiences linguistically and culturally, or to impose on them the source language foreign structures and modes of thinking. The translator's preference between these two techniques is not as clear cut as Venuti suggests. Factors such as the language distance between the SL and the TL, the translated text's subject matter, the language dominancy, and the translator's level of acquaintance with the various cultural facets of both the TL and the SL should also be taken into consideration in such preference.
\end{abstract}

This paper is an attempt to investigate the subtitling translation of the American films in the Arab world in terms of Venuti's dichotomy of domestication and foreignization. It is based on a case study which examined the Arabic subtitle of two American films; "The Aviator" and "The Departed", and the English subtitle of the Egyptian Arabic film "Hassan wa Murkis".

Key words: Subtitling translation, domestication, foreignization, Venuti, Arabic. 


\section{Introduction}

For the first time in the history of mankind we are witnessing the emergence of some kind of a globalized culture manifested in various types of demonstrations along the globe. As a result of the great revolution of information technology which has changed the face of the world, people, around the world, continue to share more and more experiences and interests. Yet, it is obvious that such homogenization of shared experiences is monopolized by the western culture owing to several political, military, and economic practicalities. In this reference, Mazrui (1998:3) distinguishes clearly between the principle of homogenization which is one of the manifestations of globalization through which people start to "resemble each other to a much greater degree than (they) ever did in the past, regardless of the physical distance", and that of hegemonization of the western culture which he defines as "the paradoxical concentration of power in a particular country or civilization". These two principles have been integrated together and function as a complete whole. In the same reference, Cronin (1996:197) (cited in Szarkowska: 2005) states that "globalization is generally synonymous with unidirectional Anglicization, the dominance of the English language and Anglo-American culture at the expense of other languages and cultures".

Language, as the most essential means of human communication, is unsurprisingly playing a leading role in establishing the ethics of this global human culture. The prominent position of the American English in the whole world is simply one of the natural consequences of the cultural homogenization of our age of globalization. The lingua franca status of the American English has been consolidated by the innovative development of the digitalized current media. The revolutionary progress in the quantity and quality of the audiovisual programs such as films, TV series, documentaries, soap operas, sport programs etc. is a clear evidence of such innovation.

The film industry as one of the most powerful exhibitions of the current global media has been exploited so skillfully by what some scholars (e.g. Herman \& Chomsky, 1988 and Edward S. Herman \& Robert W. McChesney, 1997) call the media imperialists in the western world in general, and in the United States in particular. Herman \& Chomsky (1988:306), for instance, assume that the mass media in the United States "are effective and powerful ideological institutions that carry out a systemsupportive propaganda function by reliance on market forces" (cited in Wikipedia). A typical example of such institutions is Hollywood cinema which has always been used as a promotion to popularize the American culture around the world. Maisuwong (2012:1) assumes that "the promotion of American culture through films is a phenomenon where America subtly wants to dominate the world by spreading out its own culture and tradition through films". Maisuwong (ibid) selected 30 Hollywood films to investigate the concept of cultural imperialism that "America tries to communicate towards the world audience". He found that the majority of his survey pool had a strong tendency to use the American slangs and jargons used in the films, adopted the lifestyle of the films' celebrities in their real life; and adopted the ideologies and cultural values implied in the selected films.

The choice between dubbing and subtitling to the American Hollywood films selected by various European governments might shed some light on how these governments are in aware of the cultural and political messages implied in these films. 
In an interesting paper entitled "Dubbing as an Expression of Nationalism", Martin Danan (1991) mentions the following statistics about the numbers of imported films collected from various official agencies or governments that were domesticated form 1951-1962: Italy 30.3 \%, West Germany $19.6 \%$, Spain $23.7 \%$, Sweden 7.6\%, Denmark $4.5 \%$, Finland 5.4\%, and Norway 3\%. According to Danan (ibid: 608), the American film industry, during and at the post World War II era, had the required equipment and thus monopolized the market and flooded the whole Europe with Hollywood films. The governments in some European countries (e.g. France, Italy, Germany, Spain) needed some time to establish specific regulations to control the influence of the American films in their own societies. In the same reference, O'Connell (1996) and Izard (2000) suggest that subtitling is usually selected in countries with small population, whereas "political entities such as Wales, the Basque country and the Catalonia opt for dubbing as a way of promoting and/or standardizing a minority language (cited in Chiaro, D., 2009:pp.143-144).

As far as the translation process is concerned the concept of cultural imperialism has been tackled by several translation theorists. In his well-known book: "The Translator's Invisibility" (1995), Lawrence Venuti discusses the hegemony of the western culture since the postwar period stating that "foreign publishers have exploited the global drift toward American political and economic hegemony in the postwar period, actively supporting the international expansion of Anglo-American culture" (ibid: 15). Following the German philosopher Friedrrich Schleiermacher (1813) and Lefevere (1977), Venuti proposes two principles of translation; domestication which he defines as "an ethnocentric reduction of the foreign text to target language-language cultural values", and foreignization as "an ethnodeviant pressure on those values to register the linguistic and cultural difference of the foreign text, sending the reader abroad". He concludes that in order to stop the hegemony of the Anglo-American culture which result in an imbalanced exchange of culture, it is advisable for a translator to adopt the foreignization approach which might be considered as "a form of resistance against ethnocentrism and racism, cultural narcissism and imperialism, in the interests of democratic geopolitical relations" (ibid:20).

Venuti's main notion of the hegemony of the Anglo-American culture has been refuted by some scholars. Anthony Pym (1995), for example, assumes that translators are to be considered successful when their translations read natural and fluent and hence they would be more invisible to target language reader. He emphasizes that the tendency towards domestication is international and has nothing to do with what so-called hegemony of the Anglo-American culture. He states:

\footnotetext{
Here I have an interesting paper by Maria Helena Luchesi de Mello, a Brazilian who puts a bit of Venuti to work in her survey of contemporary literary translations in Brazil. Not surprisingly, she finds that the Brazilian press praises fluency just as much as the American and British press ... Venuti is thus applicable in Brazil, so the regime of invisibility could be just as strong there (I might say the same for Spain or France) as it is in Anglo-Americandom. (ibid: 5)
}

At the other extreme, the Dutch translatologist Nico Wiersema proposes the concept of "excessive translation" to refer to those types of translation that fail to 
foreignize the source text which he considers a defect. He assumes that translations in the future should be, to some extent, foreignized. He states that "the practice of literary translation has changed as a result of globalization, that texts have become more exotic, and these translation thus contribute to a better and more correct understanding of the source culture" (Wiersema: 2003, online).

\section{Subtitling Translation}

\subsection{A Brief History:}

Subtitling translation, unlike the other fields of translation, did not receive a clear interest in the academic studies as an autonomous discipline until recently as a result of the great advancements of the digital revolution. The first conference held to discuss issues related to subtitling translation was held by the European Broadcasting Union at 1987 in Stockholm under the title "Conference on Dubbing and subtitling" which paved the way towards more comprehensive studies that reached their prime age in the 1990s with publications as that of (Gambier, 1995, 1996, 1998) and (Gottlieb, 1997a, 2001) followed by huge amount of research since then (Cintas, 2009:pp.3-5).

The interest in the academia emerged in the 1980s in writing about subtitling translation does not imply that subtitling as a technique had not been used earlier in film industry. Baker (1998) assumes that subtitling appeared in Europe since 1929 when the first talkies started to be performed. Sponholz (2003:6) states that subtitles were introduced as a form of intertitles which he defined as an "a replacement shot for a part of a film that contained verbal information in the original language" (cited in Ghaemi \& Benyamin, 2010:41).

\subsection{Definitions and Types of Subtitling}

Various definitions for subtitling translation have been suggested by different scholars. O'Connell (2007:169) distinguishes between the two major forms of audiovisual translation of subtitling and dubbing assuming that subtitling is "supplementing the original voice soundtrack by adding written text on screen, and dubbing is replacing the original voice sound track with another voice in another language". Díaz Cintas \& Remael, (2007: 8), on the other hand, assume that "subtitling may be defined as a translation practice that consists of presenting a written text, generally on the lower part of the screen, that discursive elements that appear in the image (letters, inserts, graffiti, inscriptions, placards, and the like), and the information that is contained on the soundtrack (songs, voices off). Another definition is provided by (Gottlieb, 2005: 244) who describes subtitles as "captions, (or) transcriptions of film or TV dialogue, presented simultaneously on the screen"; adding that "subtitlers usually consist one or two lines of an average maximum length of 35 characters. As a rule, subtitlers are placed at the bottom of the picture and are either centered of left-aligned".

Gottlieb (ibid: 247) assumes that it is important to decide whether we deal with subtitling as linguistic or a technical process. Linguistically speaking, there is the intralingual subtitling which is performed to serve deaf or hard-hearing people and foreign language learners; it implies rendering speech to writing. The second type is the interlingual which transfers speech in a source language to writing in a target language. On the other hand, technically speaking, there are two types: Open subtitles which includes cinema subtitles and interlingual television subtitles which is usually not optional, and the close subtitles, the optional one, is provided to serve the deaf and hardhearing people and selected by individual viewer by a remote-control unit. 


\subsection{Characteristics of Subtitling}

The European Association for Screen Translation held a meeting in Berlin at October 1998 and approved some constraints that translation agencies should comply with. These constraints are presented as statements in (Ericson, N. 2009: 2) such as "translation quality must be high with due consideration to all idiomatic and cultural nuances, straightforward semantic units must be used, subtitles texts must be distributed from line to line and page to page in sense block and/or grammatical units, the language should be grammaticality correct since subtitles serve as a model for literacy" assuming that these constraints are just guidelines that might help the subtitlers basically in dealing with the culture specific items.

Luyken et al. (1991:31 cited in Liu, D.:2012), who consider subtitling as a "post-production activity" and focuses on the idea of synchronization with the "corresponding portion of the original dialogue", assume that subtitling exhibits the different characteristics: It is a mode of audiovisual translation and a type of language transfer; it is performed by a transcription of film of TV dialogues by rendering oral source text into written taking into consideration the linguistic and extra-linguistic elements involved (e.g. letters, graffiti, captions, songs); subtitlers are not simply replacing the source text by writing it on the screen as the text should be synchronized and harmonized with both the original dialogues and their corresponding actions; subtitlers should take into consideration the maximum speed of eight syllables per second proposed by Nida (1964-2005), or the 35 characters of an average maximum length proposed by Gottlieb (2005).

In (Munday, J.: 2009), Chiaro, D. (pp. 141-165) talks about subtitling translation as an integral part of the process of watching films and hence it is there to deal with both the visual and auditory aspects found in the film. Thus, the subtitler should take into consideration factors like actors' movement, facial expressions and gesture to scenery, costumes and use of lighting and color together with acoustic code and nonverbal sounds such as background noise, sound effects and music. She concludes that "screen translation is concerned mainly with conveying the verbal audio codes of an audio visual product into other languages." Chiaro, D. (ibid: 148), on the other hand, discusses three main processes that a subtitler has to take into consideration to produce an optimal subtitle which are named as "elimination, rendering, and simplification" produced originally in Antonini (2005: pp.213-14). Elimination is related to disregarding those aspects which are related to the form rather than the essence of the meaning implied such as hesitations and redundancies together with those aspects that might be interpreted by their visual existence such as a node or shake of the head; rendering, moreover, is related to features such as different source language varieties and taboo language implied, whereas condensing the syntax of the source text so as to be friendly enough to the target user is related to the third process of simplification.

In the same reference, Baker, M. (1998:245) assumes that subtitlers have to consider the film as a semiotic structure with four channels; the verbal (e.g. dialogue, background voices) non-verbal auditory channels (e.g. natural sounds, music), together with the verbal visual (e.g. subtitles and writing within the film) and non-verbal visual (e.g. composition of image, editing) channels. Moreover, subtitlers are involved in three different points related to "time and duration": Time for production of the original, time for presentation the original, and time for presentation of the translation assuming that "synchronous translations types (for example subtitling) and non-synchronous types (for 
example interpreting) are contemporal, i.e. they are connected to the original space and time" (ibid: 246).

\subsection{Constraints on Subtitling}

There are many obstacles that a translator is confronted with in subtitling a film or a TV program. Firstly, the subtitle has to be synchronized with the information provided by the other channels (e.g. dialogues, background music, sound effect, sign language etc.); any contradiction between the two sources of information might lead to misinterpretation or misunderstanding. Another types of synchronization a subtitler has to consider is that of timing speed the viewer is able to read as "the text contained in the subtitles cannot be too extensive when related to how long it will be on screen; otherwise the audience will not have the time to read them completely and still pay attention to other features of the scene" (Nobre, 2002:2).

Other scholars discuss the technical constraints that might be taken into consideration in subtitling. One of the main essential technical constraints is that of spatial parameters or layout available for subtitles at both television and cinema screens. In this reference, Kay (1999:pp.1-2 cited in Thawabteh, 2011: 209) states that "the amount of dialogue has to be reduced to meet the technical conditions of the medium and the reading capacities of non-native language users." There are several procedures that a subtitler might use to overcome such technical constraint; for instance he may make use of the other available channels to understand the message intended in the communication (see 2.3.) the choice of lexicons with letters that might take less space (e.g. I, and t, instead of w, m) (ibid: 210).

The constraints on subtitling have been tackled by several researchers from different perspectives. Bogucki, K. (2004) assumes that it is more appropriate to discuss the constraints on subtitling in terms of the concept of relevance theory of Serber \& Wilson (1986) which proposes that hearer/reader audience continues searching for the relevant meaning in any given communication and the moment he arrives at the most related one the processing stops (see figure 2.1.).

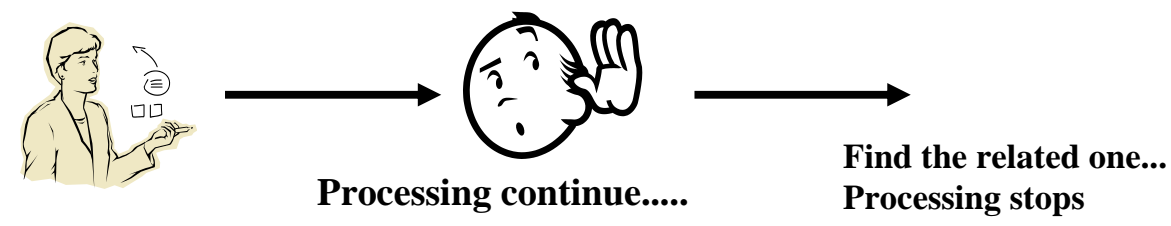

Figure 2.1. Relevance Theory

Despite the fact that the basic conceptions of relevance theory are directed towards what is called by Bogucki "primary communication" not secondary like translation, yet it might be related to film subtitling as it suggests that the subtitler is not required to be so explicit since he should take into consideration the audiences' expectations and inferences. He concludes that "relevance theory is seen as a tool to investigate what it is that can be done away with for the target text to meet the conventional criteria for acceptability" (Bogucki, K., 2004:75).

In the same reference, Tian, Chuanmao (2013) proposes an integrated approach to subtitling by combining elements of relevance theory and Skopos theory which is an approach to translation presented by Vermeer (1978) in Germany which represented a move from the highly formal linguistic approach to a more functional approach which takes into consideration the sociocultural factors involved. Tian (2013:35) assumes that 
the basic assumptions of Skopos theory which designs the translation strategies on the basis of target language contexts and cultural background, is suitable to film translation as the subtitler is expected to be well informed of "the changes caused by the transfer of a film or program to a different culture."

\subsection{The Difference between Subtitling and Other Types of Translation}

With reference to the difference between subtitling as a mode of audio visual translation and literary translation, Neves (2004:135 cited in Thawabteh, 2011: 208) assumes that a subtitler faces the same problems that a translator in literary translation faces but the fidelity factor in audio visual translation is interacting with constrains that go beyond the words or languages. She concludes: "Whereas in written translation fidelity lies in two extreme points, the source-text or the target-text, in audiovisual translation fidelity is particularly due to an audience that is in need of communicative effectiveness, rather than in search of artistic effect."

In (Munday, J.: 2009), Chiaro, D. (pp. 141-165) assumes that there is a clear difference between translating for screen and translating print as books, newspapers are translated to be read although they contain various types of illustrations such as pictures, graphs, figures etc., they are there to complement the verbal content of the written text. On the other hand, audiovisual translation are products introduced for the screen (e.g. films, TV series, documentaries etc.) which function simultaneously on two different levels. She adds that there are several non-verbal and verbal factors which might be visual or acoustic which construct the ploysemiotic of audiovisual products (see 2.3.).

\section{Related Literature}

The application of Venuti's dichotomy to both literary and audiovisual translation has been carried out by many researchers across the world. Following are examples of some of the case studies which are related to this study in one way or another.

- In an ambitious project called "Scandinavian Subtitles", (Pedersen: 2007) investigated the Scandinavian subtitles of one hundred English films and TVprograms emphasizing on the culture specific items such as education, food, government, titles, and others. Based on some previous research (e.g. Nedergaard Larsen: 1993 and Ritva Leppihalme 1997), he created his own model of translation strategies ranging from the most foreignized to the most domesticated ones concluding that "TC (target culture) substitution is most common in titles and in the government sector in both languages" (Danish and Swedish).

- Following the same technique of ECRs, Henrik Gottlieb (2009) investigated the English subtitles of five Danish films and the Danish subtitles of two American films (ibid: 25) to compare the localisms in the English subtitles with that of Anglo-American localism in the Danish subtitles of the two American films. Gottlieb did not use Venuti's dichotomy of domestication and foreignization; instead, he used two comparative concepts of maximum fidelity (source language oriented) and minimum fidelity (target language oriented). He found that the minimum fidelity in the English subtitles of the Danish films is greater (59\%) than that in the Danish subtitles of the American films (35\%), whereas the maximum fidelity in the English subtitles is less (44\%) than that in the 
Danish subtitles (67\%). Gottlieb's conclusion might be illustrated in the following figure (2.1).

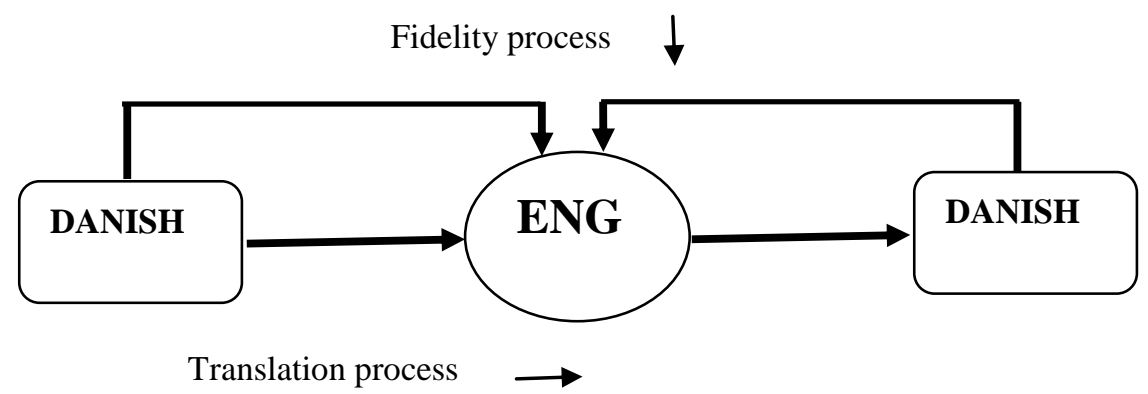

Figure 2.1 Gottlieb's (2009) Conclusions of Subtitling Translation

- Reaching the same conclusion as that of Gottlieb (2009), Espindola, E \& Vasconcellos, M. (2006) investigated the "culture-bound terms" in the Portuguese subtitles of An American film (Boys 'N the Hood) and the English subtitles of a Brazilian film (Cidade de Deus). They proposed that the direction of translation from English to Portuguese would affect the way the subtitlers treat the cultural elements and such treatment would be related to the representation of the two cultures involved. Their quantitative data show 29 domesticated instances in the subtitles of the Brazilian film and only 1 foreignized instance in that of the American film. On the other hand, there were 11 domesticated instances in the subtitles of the American film, and 18 foreignized instances in the subtitles of the Brazilian film (ibid: 52).

- Building on Pedersen's project (2007), Ericson, N. (2009) investigated the Swedish and French subtitles of two American films to see if the subtitlers follow comparative procedures and norms. She proposes that Sweden, as a smaller country in comparison to France, "may be more Americanized culturally" and hence the Swedish subtitlers would be more comfortable in domesticating the American ECRs found in the films. In her qualitative evidence, she found that there are particular difference with reference to domestication process conducted by the Swedish and French subtitlers as the "French subtitlers tend to domesticate to greater extent than Swedish subtitlers do, in the case of the transference of ECRs" (ibid:20).

- Rodka Kolebáčová (2007) investigated the domestication and foreignization in the Czech subtitles of seven American films to validate or refute two hypotheses; the first is that in subtitling the culture specific items addressed to young audiences, subtitlers would tend to use the domestication translation strategies such as neutralization, substitution, and explication, whereas they would use foreignization strategies such as transference and naturalization when addressing adult audiences. The second hypothesis is based on a comparison between two types of subtitles for the same films performed by professional and non-professional subtitlers assuming that "the professional subtitles (would) tend to use transference, cultural equivalent, and paraphrase, 
(whereas) the non-professional subtitles (would) favor transference, neutralization and deletion to a higher extent" (ibid: 2).

- Nathalie Ramiere (2006) investigated Venuti's dichotomy in the translation strategies used in the French subtitles and dubbing of three American films. Similar to most of other related studies, she studied the cultural specific references to observe the validity of the translation strategies used in the translation of these references and how such validity might affect the cultural relatedness between the source and the target texts that she calls the "Self" and the "Other". She concluded that the model that she used to study the translation strategies did not succeed to identify the pragmatic nature of the cultural transfer and thus "instead of regarding Self and Other, Familiar and Foreign, as fixed notions, it is more faithful to see them as mutually defining since, according to the existentialists, the Other is always more less constructed from the Self and defined in relation to the Self" (ibid: 155).

- Bouzaine, Karima (2010: pp. 52-64) studied the cultural transfer in the Arabic translation of brand names of cosmetics in English advertisements. Based on a target-oriented approach of Guidère's (2008) and Smith's (2006), the researcher used a corpus of 400 printed advertisements in English with their Arabic translation published in 2009 and 2010 to study three types of translation strategies implemented (transplantation, transliteration, and transmutation). She found that $95 \%$ of the brands were transplanted with $80 \%$ of them were transliterated and 5\% transmuted. She concludes:

The fact that the foreignizing strategies are frequently used in translation of

adverts from English into Arabic suggests the dominance the "Otherness" which is used so positively. This indicates that Americanization is still seen as attractive in the Arab world. Advertisers strive to ensure that the product/company name plays a part in the selling process in the original English advert (Bouzaine, 2010:61).

- Thawabteh (2011: 207) investigated the lexical problems that the Arabic subtitlers might encounter with in film subtitling into English. He asked 15 MA translation Arab students to provide English subtitles for an Egyptian Arabic film. He found that the students faced difficulty not only in arriving at the proper equivalent that covers the referential and expressive aspects of meaning, but also in solving the various technical problems such as the limited time and space available for each subtitle. Moreover, he assumes that the use of American rather than British English seems to save extra characters and the use of "componential analysis approach for a SL item is highly recommended for the sake of narrowing the lexical gab between the SL and TL".

- In another study (Thawabteh, 2012: pp. 145-157), the researcher focuses on euphemism and dysphemism in Arabic-English subtitling. He investigated the English subtitle of another Egyptian Arabic film assuming that the difficulty of translating these two processes is not only ascribed to their culture-specific nature but also to the technical dimension involved such as the number of characters involved, synchronization, and segmentation problems. The study 
concludes that a subtitler has to select one of the following translation strategies:

(1) SL euphemistic or dysphemistic expressions are rendered into TL free euphemistic and dysphemistic expressions; (2) SL euphemistic or dysphemistic expressions are translated into TL euphemistic or dysphemistic expressions; and (3) SL free of euphemistic or dysphemistic expressions are transferred into TL euphemistic or dysphemistic expressions.

Venuti's dichotomy of domestication and foreignization is based mainly on cultural and political considerations and hence the majority of case studies that used such dichotomy to investigate the translation strategies used in film subtitling concentrate on various types of taxonomies to culture specific items. In this reference, Nida (2001:82) assumes that "for truly successful translation, biculturalism is even more important than bilingualism, since words only have meanings in terms of the cultures in which they function. Cultural gabs between the source language and the target language have always turned to be hard nut for translators to crack" (cited in Wenfen Yang: 2010). Yet, some case studies have been carried out to observe some linguistic perspectives that subtitlers of films might encounter.

Mahadi, T. et.al. (2010) assume that the concept of linguistic hegemony might be considered in parallel to that of political and cultural hegemony of the AngloAmerican countries presented in Venuti (1995 \& 1998b) which influences in one way or another the translators' decision to domesticate the texts translated into English. Based on some earlier research such as (Gavioli \& Zanettin 1997 \& Zanettin et. al. 2003), they assume that the internet provides the translators with an enormous English virtual corpus to check the various linguistic aspects of the phrases or sentences they select in order to arrive at the naturalness of the texts. They conclude that "target language corpora...provide translators with a range of linguistic options to say things in TL and the translator can choose or adopt the ones that best suit what the source text is saying" (ibid: 6).

\section{Subtitle Translation in the Arab World}

\subsection{A Brief History}

A few years after the manifestation of what is called the "pre-Hollywood" cinema in Europe (1890-1910), the hegemony of the post First World War Californiabased American industry started to flourish gradually. Despite the fact that the style and techniques used in film industries were used all over the world during the 1920s onwards, the United States and only few European countries started to have power over the production, distribution, and exhibition of films. Yet, the first film picture presented to paying audience is that of Lumiere brothers which was dubbed in cinematography in Grand cafe in Paris in December 1895 (Nowell-Smith, Geoffery, 1997:32).

At the time when the film industry started to emerge in Europe, the Arab world was considered as British and French protectors who divided almost all the Arab countries between them through the Sykes-Picot agreement. This led to a long period of political and economic dependency which naturally hindered any type of establishing a national film industry. Fortunately, due to several historical and cultural reasons, Egypt and Algeria were exceptions to some extent. In 1896, only few months after the Lumière brothers presented their first film to the French audiences, the film was shown to their 
counterpart Egyptian audiences. In the same year, the first cinematography appeared in both Algiers and Alexandria (Shafik, V.: 1998).

Although the films were silent with a dialogue flashed on the screen between scenes, Egyptians showed interest since the beginning and by the end of the First World War there were 80 film theaters showing French and Italian pictures. Yet, the technique of synchronizing translation at the bottom of the screen was not developed, so the management had to hire an "explicateur" commenting in Arabic. Later on, Cairo's Olympia cinema developed a system which provided the Arabic subtitles in a smaller screen beside the main one which showed the film (Tewfic, S., 1965:13)

\subsection{The Characteristics of Subtitling in the Arab World}

Gamal M. Y. (2008: pp.2-5) assumes that the work of the well-known Egyptian subtitler Anis Ebaid is considered the first authentic and official one which dominated the audiovisual scene in the Arab world from 1944 to 1989. American films were subtitled by Anis Ebaid in Egypt and distributed, later on, to all other Arab countries. The emergence of subtitling the American films was accompanied by the emergence of film industry in Egypt; both of them were subject to strict official governmental regulations related mostly to the use of taboo language and violence. As a consequence of such strict legislations, the written Arabic appeared on the screen developed its own language genre. Gamal (ibid) collected some newspaper and magazine clippings on subtitling published in several Arab countries in the period from 1980 to 2004 which included several modes of audiovisual translation and dealt with it in linguistic and technical terms coming up with the following characteristics:

-Television language 'Televese' is too stiff.

-Deletion appears to be a prominent strategy

- Swear words are too clichéd.

- Cultural images are mistranslated

-Translation of film titles is too liberal

- Language of subtitling is becoming a genre.

- Mistakes are always to be expected.

- Subtitles are too small and too fast to read

- Spotting is a major source of irritation

-White color of subtitles is unhelpful

Despite the fact that the above characteristics have not yet been subject to verification, to the best of the researchers' knowledge, due to the limited number of studies conducted in this field, they still represent an initiative promising start that might pave the way to some further research. One of the most essential features that this study is talking about is the fact that the Arabic subtitles of the American films particularly that of Anis Abaid followed by the new center of the official Egyptian TV have created an Arabic genre on its own which was then called the television language. In this reference, Gamal (ibid: 4) states:

As television increased the dose of subtitled programs, a new genre of on-screen language or Televese came along. The new AVT center at the Egyptian television (and indeed the work of Anis Ebaid) entrenched the feeling that television has its own language. Further, swear words had to be sanitized, sexual references deleted and blasphemous references expunged. The way subtitlers dealt with this triad of taboos, relied on certain lexical items and syntax that was odd 
and stilted. Not only is the spoken foreign language translated into written Arabic but also the spoken dialogue was read in a form of language that was not only formal but also refined. This process led to the dilution of cultural concepts as in the case of the "bar" being translated into the archaic word hana, "slut" into ahira and the four letter words into 'alayka al-la'na.

\subsection{The Current Situation of Subtitling in the Arab World}

The attached picture taken from a Facebook page introduces a shift in the new generation's conception about subtitling in the Arab World. The comment states "may God burn the factories of Anis Abaid which made half of the Egyptian society convinced that 'fuck you' means 'go to hell'"; this statement does not simply refer to the mistranslation of a phrase, but it implies a shift towards breaking some of the long-established taboos in the society. In the course of discussing the essential role of media in shaping the ideas of the new generation in the Arab world,

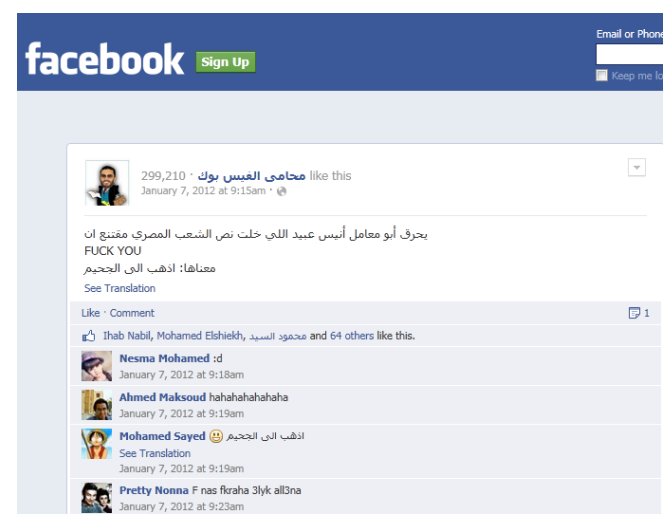
Alterman (2002: pp.66-67 cited in Darwish, Ali 2009) assumes that the Arabic satellitebroadcast television stations has caused a revolution as they "have encouraged open debates on previously taboo subjects like secularism and religion".

Most of the Arab youngsters do not depend, anymore, on official subtitles which are usually under the supervision of particular governmental organizations; instead, they have several other channels such as DVDs with unauthorized subtitling or watching films online with many alternatives of subtitles provided by fan subtitlers (e.g. http://subscene.com/).

The shift to the need of a more liberal and modern film subtitles that the new generation in the Arab world has been asking for happened due to several events such as establishing the first cable television (MBC) in 1991 together with the first Arabic telecommunication satellite Nilesat which paved the way to the appearance of very popular channels that are specialized in showing foreign films (mostly American) with various genres. In this reference, Gamal (2008: 10) states:

The increasing number of terrestrial channels created the need for more programs to broadcast. This is in turn created a demand for more subtitled programs, more subtitlers and subtitling companies. Suddenly, the scope of subtitling programs into Arabic exceeds feature films, TV series and documentaries to include reality shows, game shows, sitcoms, sports, world events and interviews.

As for the interest in subtitling translation in the Arab academia, Thawabteh (2011a:pp. 26-27) assumes that "audio visual translation, (unlike other types of translation), is still not recognized as an independent discipline in the Arab world". He made a search in two well-known translation journals and found only two papers about subtitling and no one on other modes of audio-visual translation. In the same reference, Gamal (2009:3) assumes that most of the papers written about subtitling in the Arab 
world are unpublished adding that "the audiovisual translation was neither taught nor considered a specialization of translation studies" in the Arab countries (ibid).

\section{English and Arabic:}

\subsection{Language Distance and Structural System}

Apart from the fact that English is an Indo-European language which is usually classified within the western European languages such as Dutch, Flemish, whereas Arabic belongs to a completely distant family referred to as the Semitic family of languages such as Aramaic and Hebrew, the structure of Arabic, unlike English, is mainly an inflectional and agglutinative. For example the single word "mushhankelimoh" in Egyptian Arabic has the meaning of a complete sentence in English (we are not going to talk to him). Regardless of the approach that one might use to tackle the language distance between English and Arabic, it is obvious that it is huge and such distance would naturally create a great deal of difficulty to the process of translation between these two languages. To illustrate, let us consider the following simple English sentence and how it is translated to some sister languages in comparison to its translation to Arabic (Juma: 2011).

\begin{tabular}{|c|c|c|c|c|c|}
\hline \multirow{2}{*}{ English } & \multicolumn{2}{|c|}{$\begin{array}{c}\text { Definite Article +Noun } \\
\text { Subject }\end{array}$} & \multirow{2}{*}{$\begin{array}{c}\text { Verb } \\
\text { brok } \\
\text { e }\end{array}$} & \multicolumn{2}{|c|}{$\begin{array}{c}\text { Possessive Pronoun + } \\
\text { Noun Complement }\end{array}$} \\
\hline & The & Man & & his & oath \\
\hline Dutch & De & Man & brak & Zijn & eed \\
\hline $\begin{array}{c}\text { Germa } \\
n\end{array}$ & Zum & mann & $\begin{array}{c}\text { brac } \\
\text { h }\end{array}$ & sein & schwr \\
\hline French & $L^{\prime}$ & homme & brisa & ses & Serment \\
\hline Arabic & Verb & $\begin{array}{c}\text { Definite } \\
\text { Article + Noun } \\
\text { Subject } \\
\end{array}$ & \multirow{2}{*}{\multicolumn{3}{|c|}{$\begin{array}{c}\text { Preposition + Noun +Bound } \\
\text { Pronoun } \\
\text { Complement }\end{array}$}} \\
\hline & نكث & ( الرجل ) ال رجل & & & \\
\hline
\end{tabular}

Table 5.1. Language Distance between English and Arabic

As it clear in the above table, the grammatical structure and word order are different from those in the other defined languages which might create a great deal of difficulty in the process of translation. Such differences "often result in some change in the information content of the message during the process of translation ... (a translator would either) omit the relevant information or encode this information lexically" (Baker, 1992:pp. 86-88). The choice between omission and lexical encoding (addition or specification) is related to Venuti's dichotomy of foreignization and domestication although the latter is basically cultural not linguistic. Accordingly, one may conclude that whenever there is an implied difference in the grammatical structure, a translator opts for foreignizing or domesticating the available source text.

For instance, the grammatical categories of number, gender, and case are usually functioning together to distinguish both the nouns and the demonstratives in Arabic. A translator wishing to translate the sentence "تعمل هاتان الممرضتان في المستشفى الحكومي into English has to choose between being loyal to the grammatical structure of Arabic with its semantic implication by lexically encoding the missing grammatical equivalents in 
English or being closer to the structure of English by omitting those structures (see figure 5.5.1).

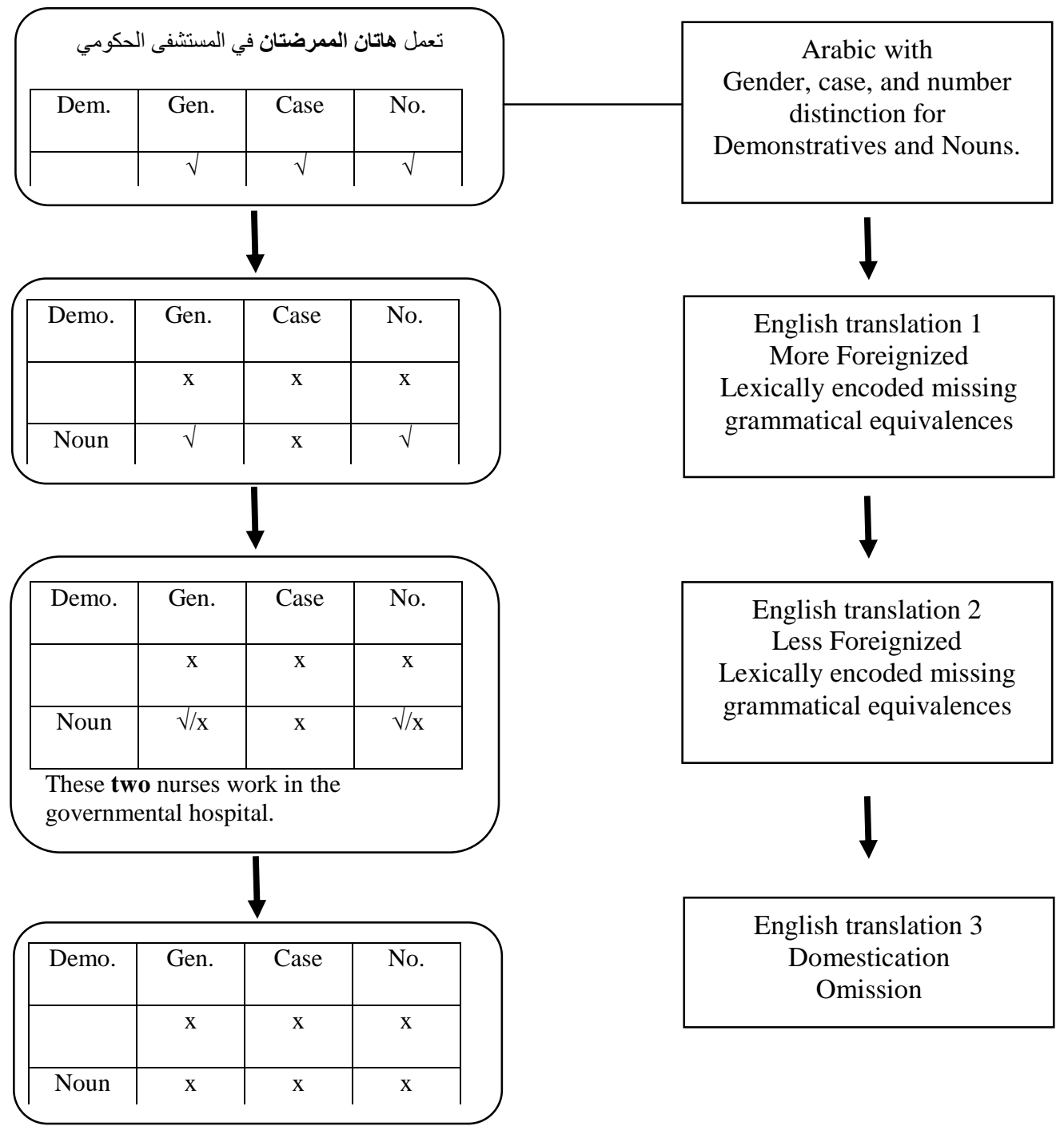

Figure 5.1.1. Choices between Omission and Lexical Encoding

As it is clear in figure 5.5.1., even if the translator chooses the most foreignized alternative to translate some sentences from Arabic into English, some aspects of the grammatical structures in Arabic have to be disregarded simply because they cannot be lexically encoded.

As far as subtitling is concerned, a subtitler likes to translate the same sentence (These nurses work in the governmental hospital) into Arabic might collect some information from the non-linguistic channels mentioned in 2.3. above (they are female nurses and they are two) and comes up with the translation تعمل هاتان الممرضتان في المستشفى الحكومي adding the three aspects of grammatical structure of gender, case, and number to both the demonstrative and noun or simply انهما تعملان في المستشفى الحكومي leaving the piece of 
information (they are nurses) to be collected by the help of the other non-linguistic channels.

Another important distinction between English and Arabic is that of word order. In this reference, Baker (ibid: 110) assumes that "languages vary in the extent to which they rely on word order to signal the relationship between elements in the clause. Compared to languages such as German, Russian, Finnish, Arabic, and Eskimos, word order in English is relatively fixed." Ellis (1994/2000: 312), on the other hand, assumes that languages vary with reference to their basic word order and with the rigid or flexible rules they stipulate with reference to their word order.

In Arabic, the process of fronting and postponement is far more varied in comparison to that in English. Classical Arab grammarians usually classified it into obligatory and optional and is ascribed to the shift in interest and consideration, on one hand, and to achieving utility (the convenience of the text receiver), on the other hand. For instance, it is obligatory to postpone the subject and front the predicator if it contains a prepositional phrase or an adverbial and the subject is neither modified by an adjective, nor associated with a genitive.

1. In starlings, there is a fear though flying

In eagles, there is glory though dying

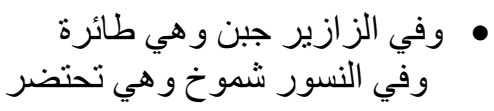

2. There is a fear in starlings though

flying

There is glory in eagles though dying

As fronting the prepositional phrase in English is stylistic not grammatical and hence optional, a translator might use sentence 1 to be closer to the Arabic structure or use sentence 2 to adhere to the canonical English word order. It should be noticed that in both cases the translator has to add "there is" as the sentence in Arabic is verbless (nominal sentence).

On the other hand, fronting might be optional in Arabic verbal sentences; for instance, fronting the object to show consideration and interest.

3. It is God whom the scientists are afraid of.

4. The scientists are those servants of

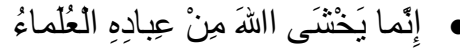

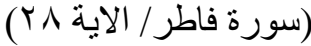
God who are really afraid of Him.

5. It is God whom I ask to help.

6. I ask God to help me.

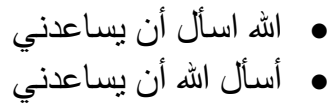

It should be noticed that fronting the object is highly marked as it is rarely found in contemporary Arabic; it is one of the major characteristic of classical Arabic used in the holly Quran. A subtitle that fronts the object in Arabic as a translation of an English sentence with it-cleft clause would seem classical and odd. On the other hand, fronting the predicator in Arabic is highly unmarked. Accordingly, a translator from Arabic to English would find that 
the unmarked predictor + subject structure would normally be translated by an equally unmarked structure such as subject + predicator rather than by an identical but highly marked structure which places the predicator in initial position. Going in the other direction, from English to Arabic, a translator should try to find some way of conveying the emphasis attached to a fronted predicator. (Baker, 1992:135)

To conclude this section, a translator or a subtitler, taking into his/her consideration the message behind fronting or postponing (in case of subtitling such message might be understood from both the linguistic and non-linguistic channels), might either domesticate the source text if he chooses to translate the marked structure to an unmarked structure in the target language to satisfy the information flow and naturalness of the text or keep the marked structure in the target language though seems foreign.

\subsection{Diglossia Is No Longer Valid; A New Stage of Arabic- English Contact}

The linguistic status in the Arab countries has always been described in terms of the sociolinguistic phenomena of diglossia (Ferguson: 1972) in which two variants of the same language are used in different contexts; in the case of Arabic: the Classical Arabic with a high prestigious position in comparison to the various Arabic vernaculars with low prestigious status. Following Badawi (1973), among many other Arab linguists, three different variants of Arabic have been identified: Colloquial (illiterate, educated, and elevated), modern formal Arabic (standard), and classical; each with its own registers and contexts.

The clear-cut distinction of contexts identified by Ferguson is no longer valid. The classical and standard variants of Arabic are losing more and more contexts for the interest of the vernaculars. For instance, the long-established attitude towards the use of vernaculars inside schools and university classrooms, inside the mosques, and in TV and Radio channels have passed through radical changes during the last few years. Such changes might be ascribed to the emergence of a new generation in the Arab world, similar to those all over the world, obsessed with all aspects of the new communication technology. Roughly speaking, people belong to these two generations are distinguished by three major characteristics (see Warschauer et al. 2002):

A. They are either multilingual or bilinguals (Arabic, English, French) with various degrees of bilingualism/ multilingualism (Hakuta \& Diaz: 1985),

B. they are less adhered to the Arab Nationalism perspectives and more inclined to the local patriotism, and hence,

C. they are more attached to the use of the various Arabic vernaculars.

On the other hand, investigating the language distance between the standard Arabic and the various Arabic vernaculars, Saiegh-Haddad (2003) (cited in John Myhill: 2009) talks about the difficulty of acquiring the standard Arabic in schools by the Arab children due to the clear language distance between their vernaculars as their mother tongues and the standard Arabic. Myhill (ibid) identifies different types of diglossia; one of them is related to Arabic in which the high language is based upon a group of prescriptive grammatical and structural rules based on an ancient language. He states:

These norms are less cognitively accessible to the child acquiring literacy because it is not based upon anyone's everyday usage so that there is no model to be imitated and its rules are more likely to be the 
invention of grammarians rather than the product of natural language acquisition.

The characteristic of the new generations in the Arab world mentioned above concerning the shift in their loyalty from the Arab nationalism principles towards their local distinguished cultures has been supported, on one hand, by the discomfiture in using the standard Arabic as opposed to their every-day language which they speak with ease, and, on the other hand, by the various technological tools provided by the new technology. Al-Tamimi and Gorgis (2007) discuss the close relation between the use of vernaculars in e-mail messages and the expressions of feelings. They found that their subjects switched from English to standard Arabic and then to Jordanian Arabic when they liked to show more intimacy or complements to maintain solidarity and even vernacular identity.

The effect of these changes in the new generation modes of thinking is clear in dubbing more than in subtitling as many American films and series have been dubbed into different Arabic vernaculars which are usually more liberal to the use of many English loanwords transferred into Arabic with their cultural background. In this reference, AL-Najar (1997) assumes that a great deal of loanwords have entered Arabic as they have traveled with their signified after they have been used in the Arab societies. As for subtitling, despite the fact that subtitlers are expected to use the standard Arabic as they are trained as students in making a good use of it, they would certainly feel more comfortable with their different vernaculars as the real languages used in their daily-life situations. In this reference, Gamal M. Y. (2008: 7) states:

With globalization affecting more and more aspects of Arab and Egyptian life, more audio-visual translation into Arabic is being carried out not in the formal and refined variety of Arabic, but in the language of the man in the street. While Arabic television commercials, print advertisements and children's cartoons are increasingly produced in "Ammeyia" (Egyptian Arabic), foreign audiovisual materials are almost universally rendered into "Fusha" (standard Arabic).

\section{Culture Specific Items in Audio Visual Translation}

There have been various types of definitions for culture provided by many anthropologists, sociologists, and linguists as each group has its own perspective. An early treatment to culture is usually ascribed to the American anthropologist and linguist Edward Sapir (1884-1939) who investigated the essential relation between language, race, and culture. He assumes that "language does not exist apart from culture, that is, from the socially inherited assemblage of practices and beliefs that determine the texture of our lives." (Sapir: 1921). Following Sapir, Lado (1957) defines culture as "structured systems of patterned behavior". Several sociologists and anthropologists have defined culture as an aspect of human behavior. It includes the knowledge, beliefs, morals, traditions, values, language etc. of a particular society.

Accordingly, language is considered as an integral part of any culture. As far as translation is concerned, it is universally accepted that translation is basically comparing cultures (Nord, 2001:34). Nida (2001:82), in this reference, assumes that it is more important for a successful translator to be a bicultural than a bilingual as the meanings of words are related to their functions at particular cultures. On the other hand, several scholars talk about cultural similarities and differences; cultural similarities or what 
some scholars call cultural universals (Gentzler, 1993:58 cited in Liu: 2102) might facilitate the process of translation as they provide some mutual universal basis of understanding, whereas cultural disparity as explained for instance in Nida (1964) and Newmark (1988) would create various types of barriers to translators. Table 5.3.1 illustrates two examples of ecology and religion as cultural disparity items between English and Arabic.

\begin{tabular}{|c|c|c|c|}
\hline $\begin{array}{c}\text { Cultural Disparity } \\
\text { Items }\end{array}$ & \multicolumn{2}{|c|}{ Examples and Translation } & Notes \\
\hline $\begin{array}{c}\text { 1. Ecology } \\
\text { The lexis of a } \\
\text { particular language is } \\
\text { closely associated to } \\
\text { the environmental } \\
\text { elements surround } \\
\text { the users of that } \\
\text { language }\end{array}$ & $\begin{array}{c}\text {-Shall I compare } \\
\text { thee to a } \\
\text { summer's day } \\
\text {-Thou art more } \\
\text { lovely and more } \\
\text { temperate } \\
\text { Cited in: Aziz, Y \& }\end{array}$ & 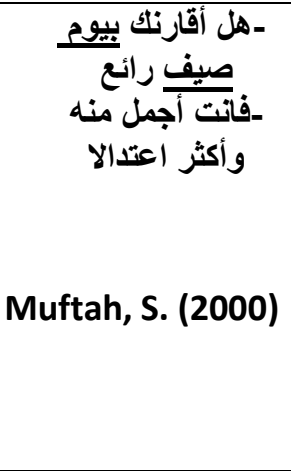 & $\begin{array}{l}\text { Shakespeare's attempt to } \\
\text { use the image of the } \\
\text { beautiful summer day } \\
\text { (lovely temperate weather) } \\
\text { is typical in the environment } \\
\text { of most of the Northern } \\
\text { European countries. This is } \\
\text { not the case in most of the } \\
\text { countries wherein Arabic is } \\
\text { used. }\end{array}$ \\
\hline 2. Religion & 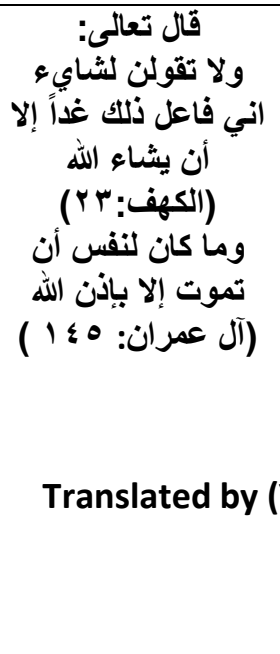 & $\begin{array}{c}\text {-Nor say } \\
\text { anything "I shall } \\
\text { be sure to do so } \\
\text { and so } \\
\text { tomorrow" } \\
\text { without adding } \\
\text { "so please Allah" } \\
\text { - Nor can a soul } \\
\text { die except by } \\
\text { Allah's leave" } \\
\text { (ussuf Ali: 1999) }\end{array}$ & 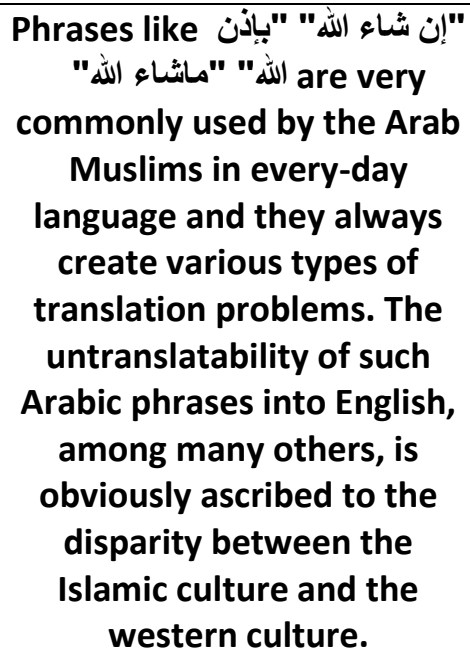 \\
\hline
\end{tabular}

Table 5.3.1 Cultural Disparity

Many other scholars investigated various taxonomies (see section 7) of what is called culture specific items or "culture specific references" (Anotonini \& Chairo, 2005:39) that create "translation crises" (Pedersen: 2005), "cultural bumps" or "cultural illusions" (Leppihalme: 1997). Pedersen (2005:2) defines what he calls "extralinguistic culture-bound reference" (ECR) as "reference that is attempted by means of any culturebound linguistic expression, which refers to an extralinguistic entity or process, and which is assumed to have a discourse referent that is identifiable to a relevant audience as this referent is within the encyclopedic knowledge of this audience." On the other hand, Leppihalme (1997:4) borrowed the term "cultural bumps" from Carol M. Archer (1986:170) who talks about the cultural problem a non-native speaker faces in communication which he believes to be mere salient than the cultural shocks. Leppihalme (ibid) tries to apply this term to translation and assumes that cultural bumps are types of illusions which occur in "a situation where the reader of a TL has a problem in understanding a source-culture allusion. Such an allusion may well fail to function in the TL, as it is not part of the TL reader's culture." Moreover, Based on (Olk: 2001), 
Ramiere (2006: 155) defines the culture-specific references with reference to subtitling translation as "the verbal and non-verbal (visual and auditory) signs which constitute a problem for cross-cultural transfer because they refer to objects or concepts that are specific to the original sociocultural context of the film."

Ramiere (ibid: 155-56) assumes that most of the research work related to the culture specific items has disregarded the audio visual translation and concentrated on textual translation except in studies like those of Tomaszkiewicz (2001) and Nedergaard-Larsen (1993). Yet, she makes use of the strategies suggested in these works and classifies them in terms of Venuti's dichotomy of foreignization and domestication. Venuti (1995:38), himself, admits that his dichotomy of foreignization and domestication is basically related to the cultural discourses stating that "critical categories like "fluency" and "resistancy," "domesticating" and "foreignizing," can only be defined by referring to the formation of cultural discourses in which the translation is produced, and in which certain translation theories and practices are valued over others."

\section{Strategies of Translation}

Many translation theorists have forwarded a variety of translation strategies along the history of translation research. An early proposal was presented by Vinary and Darbelnet (1977) (cited in Kolebáčová (2007:45) who proposed procedures like literal translation, transposition and equivalence, borrowing, claque, modulation and adaptation. One of the most comprehensive taxonomy is that of Peter Newmark in his "Textbook of Translation" (1988: pp. 68-91) in which he talks about procedures like transference: loanwords and transcription, cultural or functional equivalence, naturalization, literal translation, componential analysis, and couplet. Another important taxonomy is that proposed by Gottlieb (1992: pp. 161-170) who reduced the strategies into expansion, paraphrase, transfer, imitation, transcription, dislocation, condensation, decimation, deletion, and resignation. All these strategies have been defined with examples and used by many authors with various types of modifications resulted in several theoretical and practical problems.

One of these problems is that of inconsistency of strategies labeling as most of the researchers, in order to overcome such a problem, add their own eclectic taxonomies and hence adding more overlapping and ambiguity (Ramiere: 2006). To illustrate such inconsistencies problem, Rodka Kolebáčová (2007:42) claims that "what is called neutralization in Newmark's classification and normalization in Routledge Encyclopedia of Translation Studies is conventionalization or sanitization in Chesterman's terms and standardization for many other people." Moreover, As for Gottlieb's taxonomy, Jaskanen (1999:11) assumes that the strategies defined though seems to be clear-cut, if one try to investigate them thoroughly, they appear overlapping and subjective citing the example of the line between "condensation" and "decimation" which are defined by Gottlieb as "condensed expression, concise rendering" and "abridged expression, reduced content", whereas, that of "imitation" and "transcription" seems awkward or marginal. Another problem is how to locate these diverse strategies in a continuum of domestication and foreignization or what some authors call source language orientation and target language orientation. Ramiere (2006), for example, assumes that it is not clear whether to place neutralization and omission as examples of domestication or foreignization as they "tend to be culturally neutral and, therefore, to erase somewhat the specificity of the SC."

Apart from these problems, several scholars make use of these strategies to investigate film subtitling using Venuti's dichotomy of foreignization and domestication; the following table illustrates the model adopted in this study based 
mainly on Pedersen's model of translation strategies and that of Newmark (1988: pp. 68-91):

\begin{tabular}{|c|c|c|c|}
\hline $\begin{array}{c}\text { Foreignization } \\
\text { Source Language } \\
\text { Oriented }\end{array}$ & Description & $\begin{array}{c}\text { Domestication } \\
\text { Target Language } \\
\text { Oriented }\end{array}$ & Description \\
\hline $\begin{array}{c}\text { Retention } \\
\text { (Pedersen: 2005) }\end{array}$ & $\begin{array}{l}\text { Keeping the term in the } \\
\text { SL without change or } \\
\text { with slight } \\
\text { phonological change }\end{array}$ & $\begin{array}{c}\text { Generalization } \\
\text { (Pedersen: 2005) }\end{array}$ & $\begin{array}{l}\text { Replacing an ECR } \\
\text { referring to something } \\
\text { specific by something } \\
\text { more general because } \\
\text { the specific is not known } \\
\text { by the TL audience }\end{array}$ \\
\hline $\begin{array}{l}\text { Literal translation } \\
\text { (Newmark: 1988) }\end{array}$ & $\begin{array}{c}\text { The solution in the } \\
\text { target text matches the } \\
\text { original as closely as } \\
\text { possible }\end{array}$ & $\begin{array}{c}\text { Naturalization } \\
\text { (Newmark: 1988) }\end{array}$ & $\begin{array}{c}\text { Using the grammatical } \\
\text { and phonological rules } \\
\text { of the } T L\end{array}$ \\
\hline $\begin{array}{c}\text { Specification } \\
\text { (Pedersen: 2005) } \\
\text { A. Explicitation } \\
\text { B. Addition }\end{array}$ & $\begin{array}{l}\text { Leaving the term } \\
\text { without translation } \\
\text { attached with } \\
\text { additional information } \\
\text { A. Expansion of the } \\
\text { text (e.g. adding one's } \\
\text { first name) } \\
\text { B. Adding material } \\
\text { does not exist in the SL }\end{array}$ & $\begin{array}{c}\text { Substitution } \\
\text { (Pedersen: 2005) } \\
\text { A. Cultural } \\
\text { substitution: } \\
\text { 1. Least marked } \\
\text { (less } \\
\text { domesticated): } \\
\text { 2. Most marked } \\
\text { (more } \\
\text { domesticated): } \\
\text { B. Paraphrasing }\end{array}$ & $\begin{array}{l}\text { Replacing the ST item } \\
\text { with a different TT item } \\
\text { known by the audience } \\
\text { or change it by some } \\
\text { sort of paraphrase } \\
\text { A.1. Replaced by an } \\
\text { item expected to be } \\
\text { known by the TT } \\
\text { audience. } \\
\text { A.2. Replaced by an } \\
\text { item regardless of the } \\
\text { audience } \\
\text { B.1. With sense transfer } \\
\text { keeping the sense or } \\
\text { relevant connotations } \\
\text { by a phrase } \\
\text { B. 2. With situational } \\
\text { paraphrase: Used with } \\
\text { idioms; puns }\end{array}$ \\
\hline $\begin{array}{l}\text { Direct translation } \\
\text { A. calque (loan } \\
\text { words) B. Shifted }\end{array}$ & $\begin{array}{l}\text { Nothing is added or } \\
\text { subtracted }\end{array}$ & $\begin{array}{c}\text { Omission } \\
\text { (Pedersen: 2005) }\end{array}$ & $\begin{array}{l}\text { It simply means } \\
\text { replacing the ST ECR } \\
\text { with nothing }\end{array}$ \\
\hline
\end{tabular}

Table 7.1. Translation Strategies Based on Pedersen (2005) and Newmark (1988)

\section{The Case Study}

\subsection{The Selected Data}


In order to test the validity of the main hypothesis of this paper namely, Venuti's dichotomy of foreignization and domestication is restrained by the direction of subtitling translation into or from American English, the subtitles of the following selected films have been attested. The genre of the three selected films is comparative in one way or another.

1. The Aviator ${ }^{1}$ : The selected English-into-Arabic subtitle of this film was performed by a professional subtitling institution.

2. The Departed ${ }^{2}$ : The selected English-into-Arabic subtitle of this film was performed by two fan translators selected randomly among so many other attempts published at a website (http://subscene.com/) specialized in films subtitle translation from and into many world languages.

3. Hassan W Murkis ${ }^{3}$ : The Arabic-into-English subtitler is a fan translator.

\subsection{Procedure and Findings:}

The three above films have been selected randomly to test the hypothesis of the current paper. Some scenes of the films have been cut with their script, their subtitling translation have been written to be investigated, and the words used in the subtitles of the selected scenes have been counted (see table 8.2.1).

\begin{tabular}{|c|c|c|c|}
\hline Films & Subtitling from -into & Time & $\begin{array}{c}\text { Word Count of the } \\
\text { subtitled scenes }\end{array}$ \\
\hline The Aviator & English-into-Arabic & $21: 48$ Minutes & 1340 Words \\
\hline The Departed & English-into-Arabic & $16: 05$ Minutes & $\begin{array}{c}\text { Sample one: } 1468 \\
\text { Words } \\
\text { Sample two: } 1489 \\
\text { Words }\end{array}$ \\
\hline Hassan and Markus & Arabic-into-English & $18: 23$ Minutes & 1794 Words \\
\hline
\end{tabular}

Table 8.2.1 Data of the Study

The translation strategies presented in 7.1. have been placed in a scale of measurement (1-4) ranging from the most foreignized to the most domesticated following many other scholars (e.g. Pedersen: 2005; Ramiere: 2006; Kolebáčová: 2007) as illustrated in the following figure 8.2.1.

\footnotetext{
${ }^{1}$ The Aviator (2004): An American film written by John Logan, directed by Martin Scorsese, and acted by Leonardo DiCaprio, Cate Blanchett, and Kate Beckinsale.

${ }^{2}$ The Departed (2006): An American film written by William Monhan, directed by Martin Scorsese, and acted by Leonardo DiCaprio, Matt Damon, and Jack Nicholson.

http://www.imdb.com/

${ }^{3}$ Hassan and Markus (2008): An Egyptian film directed by Ramy Imam and acted by Omar Sharif, Adel Imam, and Lebleba.
} 


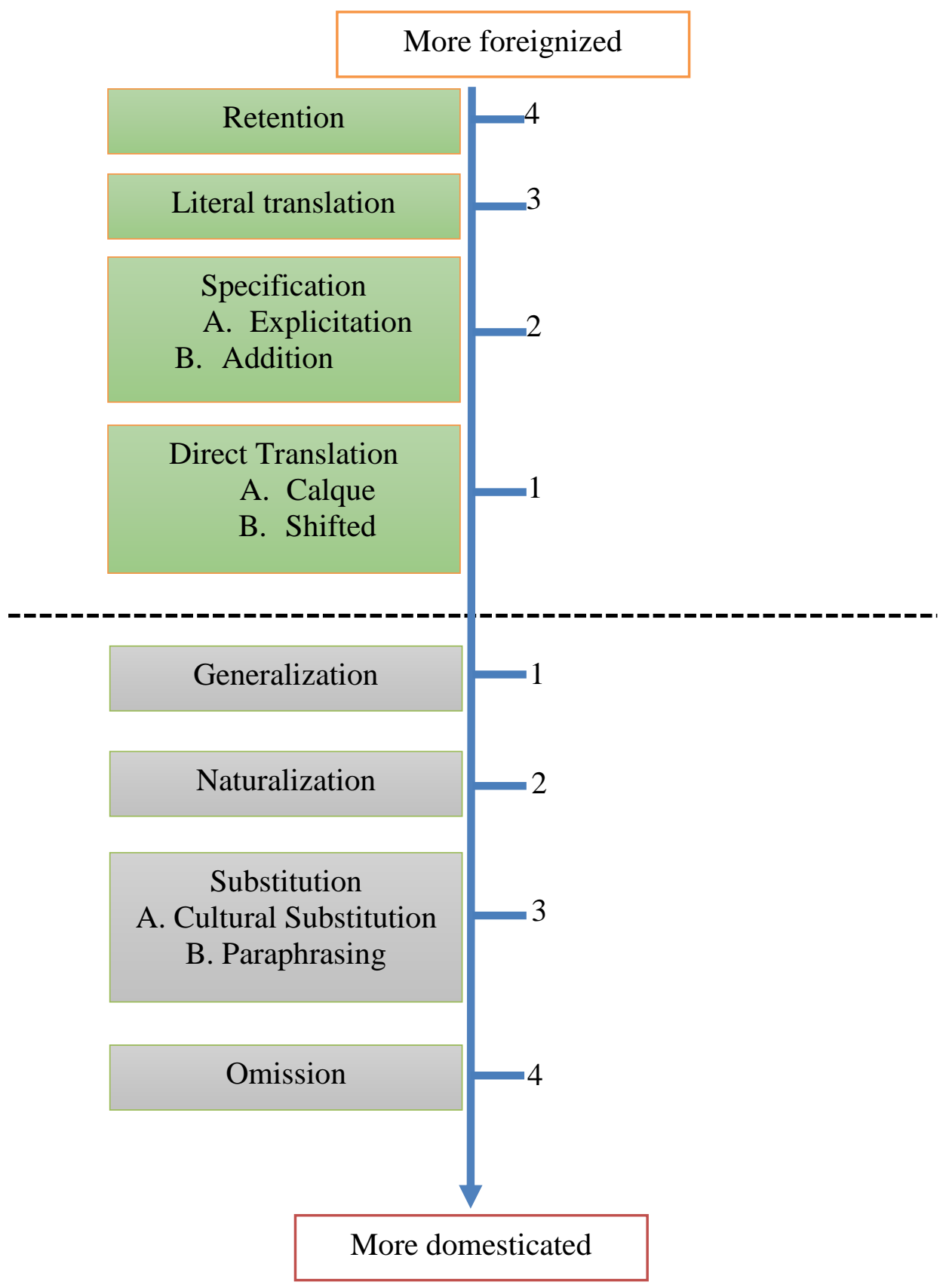

Figure 8.2.1. The Scale of Measuring the Data

The comparative texts in English and Arabic are then investigated to identify the translation strategies at different levels of structure as illustrated in the following example. 


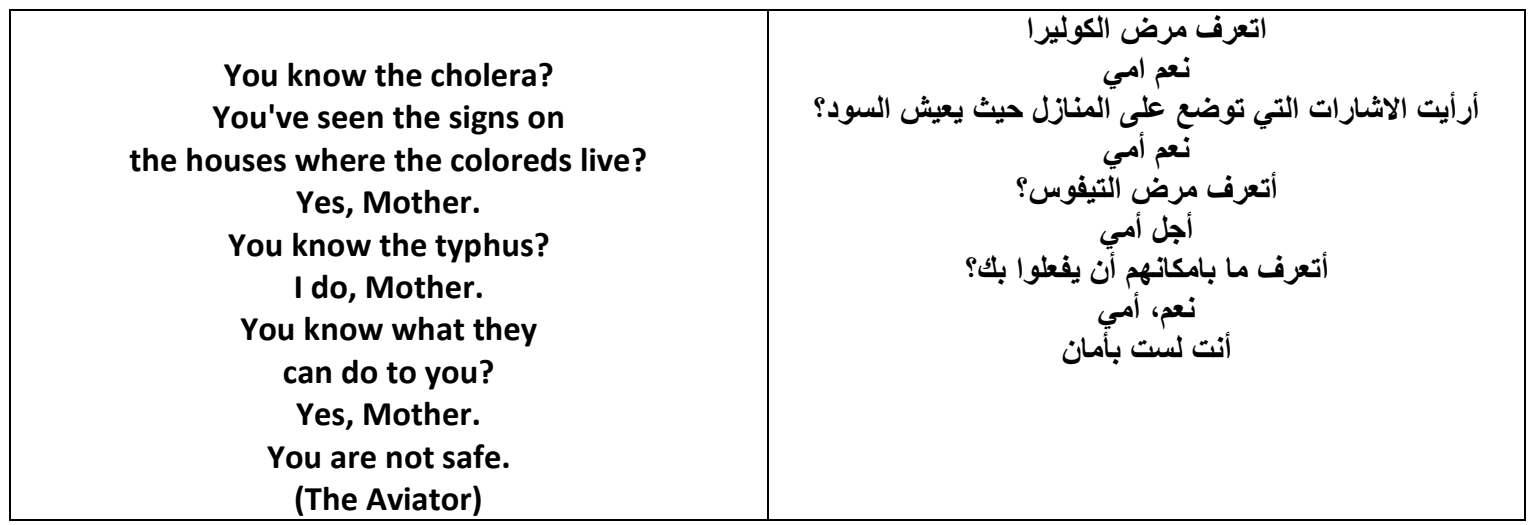

Each translation strategy is then assigned the number of points mentioned in the above scale of measurement, the total number of points is calculated, and the percentage of each strategy is designated with reference to the total number of words used in each scene.

The following tables illustrate the results of the study.

\begin{tabular}{|c|c|c|c|}
\hline \multicolumn{2}{|c|}{ SAMPLE ONE } & \multicolumn{2}{c|}{ SAMPLE TWO } \\
\hline FOREIGNIZATION & DOMESTICATION & FOREIGNIZATION & DOMESTICATION \\
\hline Total: 255 points & Total: 87 points & Total: 151 points & Total: 122 points \\
Percentage: $17.37 \%$ & Percentage: $5.92 \%$ & Percentage: $10.14 \%$ & Percentage: $8.19 \%$ \\
\hline Total no. of words: 1468 & Total no. of words: 1489 \\
\hline The summation of F points: 406 & The two samples total no. of words: 2957 \\
Percentage of Foreignization in the two samples: & Percentage of Domestication in the two \\
13.33\% & samples: 7.06 \% \\
\hline
\end{tabular}

Table 8.2.2. Statistics of the Two Samples of "The Departed"

\begin{tabular}{|c|c|}
\hline FOREIGNIZATION & DOMESTICATION \\
\hline Total points: 39 & Total points: 160 \\
Percentage: $2.22 \%$ & Percentage: $8.91 \%$ \\
\hline Total no. of words: 1794 & Total no. of words: 1794 \\
\hline
\end{tabular}

Table 8.2.3. Statistics of the Sample of "Hassan w Murkas"

\begin{tabular}{|c|c|}
\hline FOREIGNIZATION & DOMESTICATION \\
\hline Total points: 65 & Total points: 114 \\
Percentage: $4.8 \%$ & Percentage: 8.50 \\
\hline Total no. of words: 1340 & Total no. of words: 1340 \\
\hline
\end{tabular}

Table 8.2.4. Statistics of the Sample of "The Aviator"

\subsection{Discussion of Results:}

The following figure 8.3.1 illustrates the results of the study in the four samples investigated. It should be noticed that samples 1,2 , and 4 are those related to the English-into-Arabic subtitling, whereas sample 3 is related to the Arabic-into-English subtitling. 


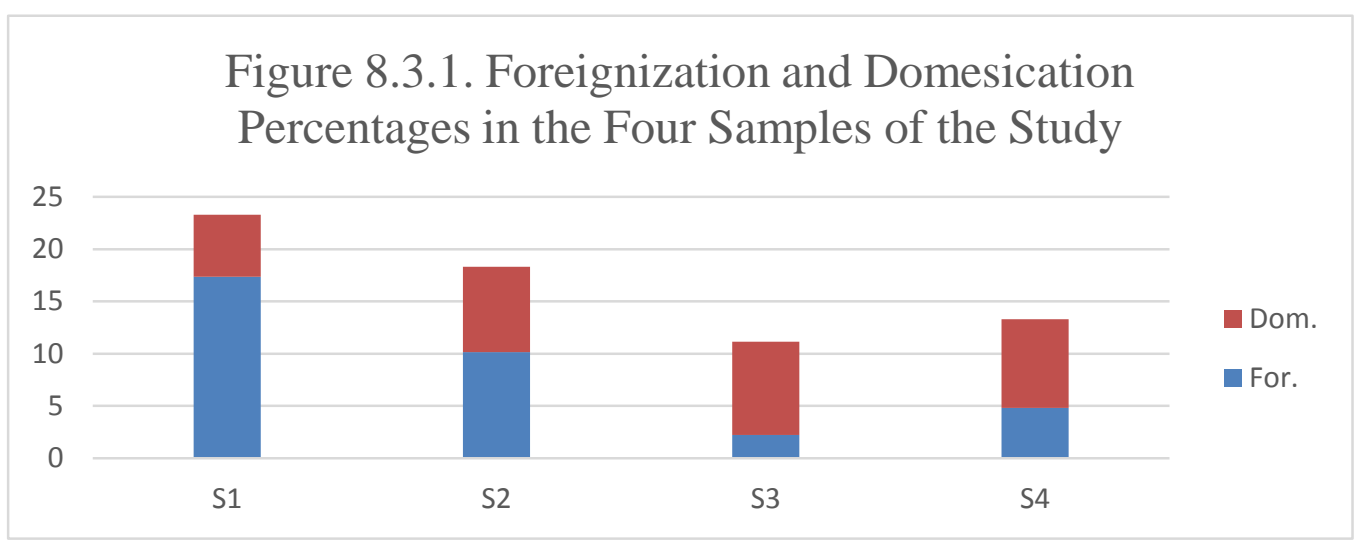

The following figure 8.3.2. compares between the percentages of foreignization and domestication with reference to the direction of subtitling.

\section{Figure 8.3.2. Foreignization and Domestication Percentages and the Direction of Translation}

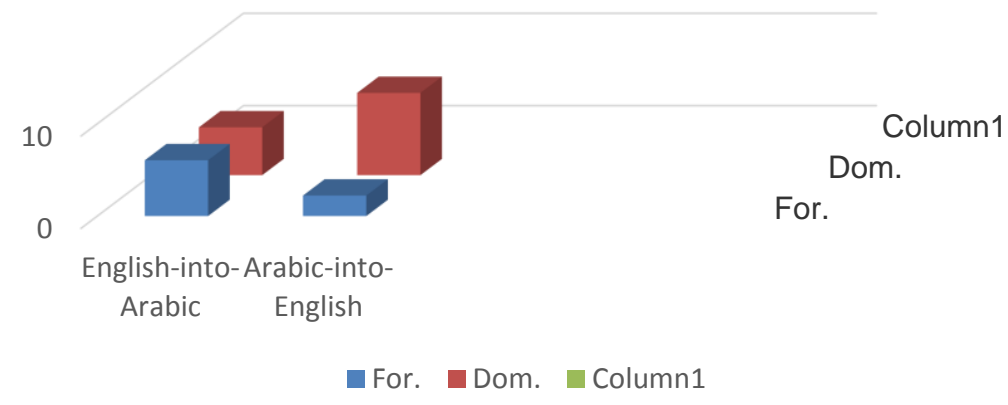

As it is clear in the above figures, the results of the study confirm the proposal that the direction of subtitling from or into English plays a crucial role in identifying the nature and the amount of a domesticated and foreignized text.

The study shows that the examples of literal translation and specification were more obvious than retention and direct translation with reference to the source-language oriented foreignized investigated text. On the other hand, examples of substitution, especially paraphrasing, and omission were more obvious than generalization and naturalization with reference to the target-language oriented domesticated investigated test. The following table illustrates examples for each one of the translation strategies investigated.

\begin{tabular}{|c|c|c|}
\hline Text in Source Language & Subtitle in the Target Language & Translation Strategy \\
\hline $\begin{array}{c}\text { As the governor of the Commonwealth of } \\
\text { Massachusetts, I am confident each and every } \\
\text { one of you will serve with distinction.(The } \\
\text { Departed) }\end{array}$ & كحاكم كومنولث ماسوش يخوستش بانـا واثث ان كل & Retention \\
\hline $\begin{array}{c}\text { Jesus. She fell funny } \\
\text { Take for instance } \\
\text { Pencils. Begin } \\
\text { Congratulations on passing the detective's } \\
\text { exam } \\
\text { (The Departed) }\end{array}$ & 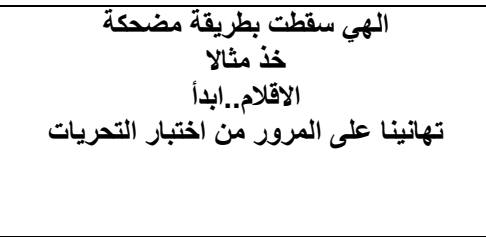 & Literal translation \\
\hline
\end{tabular}




\begin{tabular}{|c|c|c|}
\hline $\begin{array}{l}\text { Johnny, get on the horn to Universal and } \\
\text { Warners. I need two more cameras. } \\
\text { We've already spent over } 200.000 \$ \text { rebuilding } \\
\text { this plane. } \\
\text { (The Aviator) }\end{array}$ & 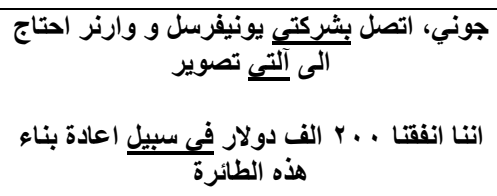 & $\begin{array}{l}\text { Specification/ } \\
\text { Addition }\end{array}$ \\
\hline $\begin{array}{c}\text { You were kind of a double kid, I bet, right? One } \\
\text { kid with your old man, one kid with your } \\
\text { mother. Your upper-middle class during the } \\
\text { weeks, then you're hanging... } \\
\text { (The Departed) }\end{array}$ & 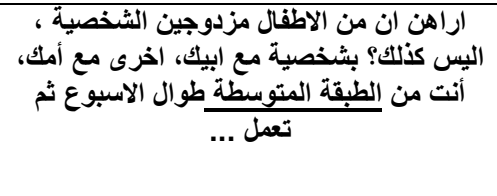 & Generalization \\
\hline $\begin{array}{l}\text { Fuck you. Fucking queers. Firemen getting pussy } \\
\text { for the first time in the history of fire or pussy. } \\
\text { Soluvia, Hey, go save a kitten in a tree you } \\
\text { fucking homos. } \\
\text { (The Departed) }\end{array}$ & 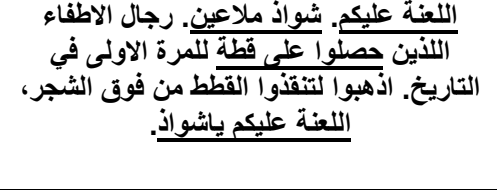 & Cultural substitution \\
\hline $\begin{array}{l}\text { The Massachusetts State Police has a long } \\
\text { tradition of excellence. Your graduation today } \\
\text { solidifies your acceptance into one of the finest } \\
\text { law enforcement agencies in our nation. } \\
\text { (The Departed) } \\
\text { Call UCLA } \\
\text { Get me the best meteorologist they got. } \\
\text { The gyro forces are too much here. You send } \\
\text { these planes into barrel rolls...they won't make } \\
\text { it } \\
\text { (The Aviator) }\end{array}$ & 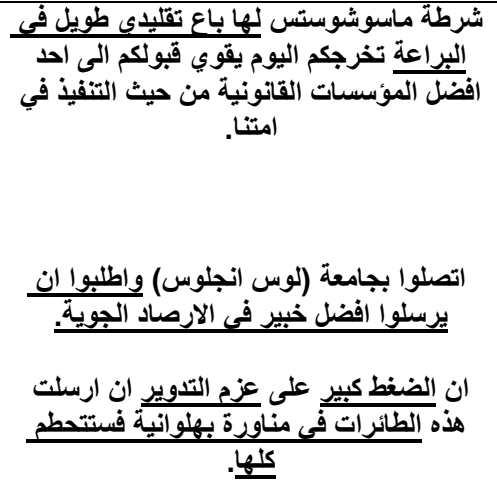 & $\begin{array}{l}\text { Substitution/ } \\
\text { paraphrasing }\end{array}$ \\
\hline $\begin{array}{l}\text { Why don't you try and make do with what you } \\
\text { have. } \\
\text { What I have isn't enough, John, not for how I } \\
\text { see it. } \\
\frac{\text { Why the hell do they look so slow? }}{\text { (The Aviator) }}\end{array}$ & 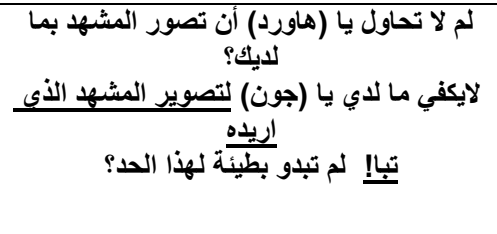 & Omission \\
\hline
\end{tabular}

\section{Table 8.3.1. Examples of Translation Strategies}

Moreover, there was no clear-cut boundary between some translation strategies used to test the data, and thus it has been difficult to refer to the strategy implied in the attested subtitle; see the following table:

\begin{tabular}{|c|c|c|}
\hline Text in Source Language & Subtitle in the Target Language & Translation Strategies mixed \\
\hline $\begin{array}{l}\text { I want minimum } 200 \text { miles all } \\
\text { right? } \\
\text { I want a date with Theda Bara. } \\
\text { That ain't gonna happen. } \\
\text { Oh, don't be so sure. } \\
\text { (The Aviator) }\end{array}$ & 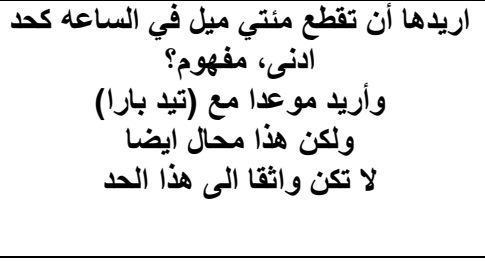 & $\begin{array}{l}\text { Paraphrasing, substitution, } \\
\text { and omission. }\end{array}$ \\
\hline
\end{tabular}

Table 8.3.2. Examples of Translation Strategies

A. In the target subtitle, the subtitler adds the pronoun "ها" which has no equivalent in the source text, and thus it might be considered paraphrasing to make the whole sentence clear to the TL receiver, and might also be considered addition as it does not exist in the original text; the same note might be applicable to the phrase "في الساعه" and the conjunction "و".

B. In the Arabic text, the subtitler uses the word "مفهوم" (literary "understood") whereas in the source text it is "right" (literary= صحيح) and thus the strategy might be both paraphrasing and substitution. 
C. The subtitler adds the conjunction "ولكن" (literary "and but") which does not exist in the source text and hence it might be considered both addition and paraphrasing as the subtitler adds it to make it more obvious to the TL receiver; the same is applicable to the addition of the phrase "الى هذا الحد" which does not exist in the SL text.

Finally, the researchers have noticed that almost all the taboo words in the target language culture when the direction of subtitling is from English into Arabic are substituted by some more morally accepted words.

\begin{tabular}{|c|c|}
\hline Text in Source Language & Subtitle in the Target Language \\
\hline $\begin{array}{l}\text { Thelma, this is Howard Hughes. } \\
\text { Howard and I were discussing how he wants me } \\
\text { to pull a camera out of my ass. } \\
\text { (The Aviator) }\end{array}$ & 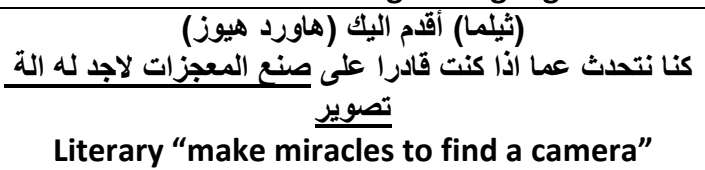 \\
\hline
\end{tabular}

Table 8.3.3. Examples of Translation Strategies

On the other hand, when the direction of subtitling is from Arabic into English, the dialogue in Arabic is mostly restricted by many cultural taboos and hence all those sexually explicit words and phrases are already banned; yet, the subtitler usually uses their original meaning expressed in English.

\begin{tabular}{|c|c|}
\hline Text in Source Language & Subtitle in the Target Language \\
\hline 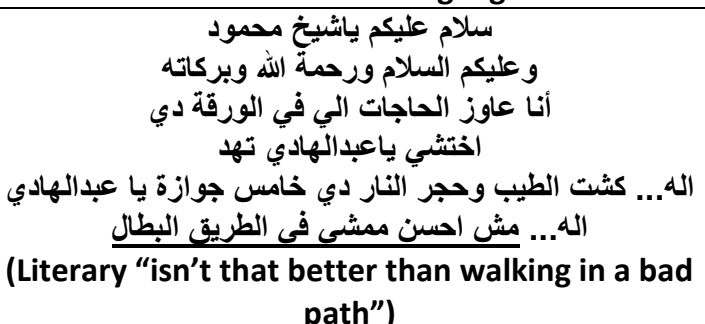 & $\begin{array}{c}\text { Good morning, Sheikh Mahmud } \\
\text { Good morning } \\
\text { I need the things in this list } \\
\text { Why don't you stop your nonsense Abdel-Hadi? } \\
\text { Take it easy. Nutmeg and fire stone? This is the } \\
\text { fifth marriage, Abdel-Hadi? } \\
\text { Isn't that better than adultery? }\end{array}$ \\
\hline
\end{tabular}

Table 8.3.4. Examples of Translation Strategies

\section{Conclusion}

The results of this study are in line with most of the studies that investigated the subtitles of some American movies such as that of (Gottlieb (2009) and Espindola, E \& Vasconcellos, M. (2006)), which illustrate clearly that the direction of the process of subtitling into and from American English used in the movies would affect the tendency towards domesticating or foreignizing the source text. The domestication technique, which leads to the invisibility of the translator and which has been criticized by Venuti (1995), has proved to be more obvious in the translation of the subtitles of the American movies than in the translation of the written books into English about which Venuti's theory originally talked. The prevalence of domesticating the source text into American English and foreignizing it from American English is ascribed to several factors. The most important one is the lingua franca position of the American English which has always been a prerequisite to cope with the modern world of our current digitalized media.

In the Arab world, despite the fact that there have always been strict regulations with reference to how far the subtitler should go in foreignizing the text used in the American movies, we have been witnessing a more liberal tendency in this reference among the new generation of subtitlers particularly those who call themselves "fan translators". TV satellites channels are no longer the favorite source of watching the 
movies as it is continuously losing their positions to various internet sites that depend almost entirely on those types of subtitling.

\section{References:}

- AL- Najar, M (1997). "Linguistic Methods for Translating Non-Arabic Signifier into Arabic", in: Issues in Translation (Ed.) by Abdulla T. Shunnaq. Irbid: Irbid National University \& Jordanian Translators' Association.

- Al-Tamimi, Y. and Dinha T. Gorgis (2007). "Romanized Jordanian Arabic Emessages", in: The International Journal of Language Society and Culture. Issue 21 (Eds.: Thao Lê and Quynh Lê.) URL: www.educ.utas.edu.au/users/tle/JOURNAL/

- Alterman, J. B. (2002). "New Media, New Politics? From Satellite Television to the Internet, in: The Arab World". The Washington Institute for Near East Policy. Washington. Executive Summary.

- Antonini, R. (2005). "The perception of subtitled humor in Italy: An empirical study", in: D. Chiaro (Ed.). Humor International Journal of Humor Research, Special Issue.

- Antonini, R. and D. Chiaro (2005). "The quality of dubbed television programs in Italy: The Experimental Design of an Empirical Study", in: M. Bondi and N. Maxwell (Eds.). Cross-Cultural Encounters: Linguistic Perspectives, Roma: Officina Edizioni, pp. 33-44.

- Archer, C. (1986). "Culture bump and beyond", in: Joyce Merrill Valdes. Culture Bound: Bridging the Cultural Gap in Language Teaching. Cambridge: Cambridge University Press

- Aziz, Y. \& Muftah S. Lataiwish (2000). Principles of Translation. Benghazi: University of Garyounis.

- Badawi, Asayid (1973). Musteweyat Al2rabia Almu3asira fi Misr. Cairo: Dar Alme3arif

- Baker, M. (1992). In Other Words: A Course book on Translation. London and New York: Routledege.

- Bogucki, L. (2004). A Relevance Framework for Constraints on Cinema Subtitling, thesis, Wydawnictwo Uniwersytetu Lodzkiego, Lodz, 185 pp.

- Bouzaine, Karima (2010). "Cultural Transfer in the Translation of Brand Names in Advertising: The Case of Cosmetics", in: Buletinul Ştiinţific al Universității "Politehnica" din Timişoara Seria Limbi Moderne Vol. 9, No. 1-2.

- Chiaro, D. (2009). "Issues in Audiovisual Translation”, in: J. Munday (Ed.), The Routledge Companion to Translation Studies. London and New York, Routledge, 141165. Copenhagen: University of Copenhagen.

- Cronin, M. (1996). Translating Ireland. Cork, Ireland: Cork University Press.

- Danan, M. (1991). "Dubbing as an Expression of Nationalism", in: Meta, XXXVI 4, pp. 606-614.

- Darwish, A. (2009). Translation and News Making: A Study of Contemporary Arabic Television: Aljazeera Case Study. PhD thesis. Queensland University of Technology.

- Dayan, Liu (2012). "Subtitling Cultural Specificity from English to Chinese", in: International Journal of Contemporary Research Vol. 2 No.10.

- Díaz Cintas, J. \& Remael, A. (2007). Audiovisual Translation: Subtitling (Translation Practices Explained, 11). Manchester, UK, \& Kinderhook (NY), USA, St. Jerome Publishing. 
- Diaz Cintas, J. (Ed.) 2009. New Trends in: Audiovisual Translation. Bristol: Multilingual Matters. 216 p. Contents in http://www.multilingualmatters.com/display.asp?isb=9781847691545

- Ellis, R. (1994-2000). The Study of Second Language Acquisition. Oxford: Oxford University Press.

- Espindola, E \& Vasconcellos, M. (2006). "Two Facets in the Subtitling Process: Foreignization and/or Domestication Procedures in Unequal Cultural Encounters", in: Fragmentos, número 30, p. 043/066 Florianópolis.

- Ferguson, Ch. (1959). "Diglossia", in Word, 15, 325-340.

- Gamal, Muhammad Y. 2008. "Egypt's Audiovisual Translation Scene", in: Arab Media and Society, vol. 5, Spring, pp. 1-15. [online] [cit. 30-11-2009]. Available at: http://www.arabmediasociety.com/?article $=675$

- Gamal, M. Y. (2009). "Adding Text to Image: Challenges of Subtitling Non-verbal Communication", in: Journal of Multicultural Research, vol. 1.

- Gambier, Y. (Ed.) (1995). "Audiovisual Communication and Language Transfer, Strasbourg 22-24.6.1995, Proceedings", in: Translatio, Nouvelles de la FIT \& FIT Newsletter, N.S. XIV, nos 3-4, pp. 197-492.

- Gambier, Yves (Ed.) (1996). Les transferts linguistiques dans les médias audiovisuels, Villeneuve d'Ascq, Presses Universitaires du Septentrion, 246 p.

- Gambier, Yves (Ed.) (1998). Translating for the Media. Papers from the International Conference Languages \& the Media. Berlin, November 22-23, 1996. Univ. of Turku, Centre for Translation and Interpreting, Turku, $317 \mathrm{p}$.

- Gavioli, L. \& Zanettin, F. (1997). Comparable Corpora and Translation: A Pedagogic Perspective. Paper presented at the first international conference on Corpus Use and Learning to Translate. Bertinoro. Retrieved April 6, 2008, from http://www.sslmit.unibo.it/introduz.htm.

- Gentzler, E. (1993). Contemporary Translation Theories. London: Routledge.

- Ghaemi, F. \& J. Benyamin (2010). "Strategies Used in the Translation of Interlingual Subtitling", in: Journal of English Studies Islamic Azad University, Science \& Research Branch, 1(1), 39-49.

- Gottlieb, H. (1992). "Subtitling: A New University Discipline", in: C. Dollerup, et al. (Eds.), Teaching Translation and Interpreting (pp. 161-70). Amsterdam: John Benjamins.

- Gottlieb, H. (1997a). Subtitles, translation \& idioms. PhD thesis, University of Copenhagen.

- Gottlieb, H. (2001). Screen Translation. Six studies in subtitling, dubbing and voiceover, Center for Translation Studies, Department of English, Univ. of Copenhagen, 161 p.

- Gottlieb, H. (2009). "Subtitling against the current: Danish concepts, English minds", in: New Trends in Audiovisual Translation. (pp. 21-46). Bristol: Multilingual Matters.

- Gottlieb, Henrik. (2005). "Subtitling", in: Baker, M. (ed), Routledge Encyclopedia of Translation Studies. Shanghai: Shanghai Foreign Language Education Press. 244-248.

- Guidere, M. (2008). The Translation of Advertisements: From Adaptation to Localization, on line, http://www.translationdirectory.com/article60.htm.

- Hakuta, K., \& Dim, R. M. (1985). "The Relationship between Bilingualism and Cognitive Ability: A Critical Discussion and Some New Longitudinal Data", in K. E. Nelson (Ed.), Children's Language (Vol. 5, pp. 319-44). Hillsdale, NJ: Erlbaum 
- Herman, E. S., \& Chomsky, N. (1988). Manufacturing Consent: The Political Economy of the Mass Media. New York: Pantheon Books. Humor and Translation, 18(2): 209-25.

- Herman, E. \& R. Mc Chesney (1997). The Global Media: The New Missionaries of Corporate Capitalism. Cassell, London, United Kingdom.

- Izard, N. (2000). "La traducció i la normalització de la llengua catalana: El cas de la televisió", in A. Engelbert (Ed.), Actes du XXIIe Congrès International de Linguistique et de Philologie Romane (Vol. III). Tübingen, Germany: Niemeyer.

- Jaskanen, Susanna (1999). On The Inside Track to Loserville, USA: Strategies Used in Translating Humor in Two Finnish Versions of "Reality Bites", MA essay, Univ. of Helsinki. Available

at: http://ethesis.helsinki.fi/julkaisut/hum/engla/pg/jaskanen/index.html

- Juma, M. (2011). "The Impact of Globalization on Translation with Special Reference to English to- Arabic and Vice Versa", in: AL-A'dab Journal of College of Arts/ Baghdad University, Issue no. 99 Vol. 334.

- Kolebáčová, Radka (2007). Culture-bound Issues in Subtitling: A Comparative Study of Films for Adult vs. Young Audiences. [online]. 2007 [cit. 2014-07-15]. Diplomová práce. Masarykova univerzita, Filozofická fakulta. Vedoucí práce Simona Javůrková. Dostupné z: <http://is.muni.cz/th/53124/ff_m/>

- Lado, R. (1957). Linguistics across Cultures: Applied Linguistics for Language Teachers. Ann Arbor, Michigan: University of Michigan.

- Lefevere, André (1977). Translating Literature: the German Tradition from Luther to Rosenzweig. Assen: Van Gorcum.

- Linde, Zoe de \& Kay, Neil (1999). The Semiotics of Subtitling. Manchester: St. Jerome Publishing.

- Luyken, G. M., et al. (1991). Overcoming Language Barriers in Television: Dubbing and Subtitling for the European Audience. Manchester: European Institute for the Media.

- Maisuwong, W. (2012). "Promotion of American Culture through Hollywood Movies to the World", in: International Journal of Engineering Research and Technology. Vol1 Issue 4.

- Mazrui, A. (1998). "Globalization, Islam, and the West: Between Homogenization and Hegemonization", in: The American Journal of Islamic Social Sciences. Volume 15, fall 1998, No.3.

- Baker, Mona (1998). (General Editor and Contributor). The Routledge Encyclopedia of Translation Studies, London \& New York: Routledge. Paperback edition (2001).

- Munday, J. (2009). The Routledge Companion to Translation Studies. (ed.) Oxon: Rouledge.

- Myhill, J. (2009). Towards an Understanding of the Relationship between Diglossia and Literacy, a Survey Commissioned by the Language and Literacy Domain Committee.

[Online]

http://www.academy.ac.il/hp.asp?file=asp/projects_new/projects.asp?txt=1\|3

- Nanna, Ericson (2009). Domestication Norms in French and Swedish. A Comparative Study of Subtitles. Department of English, Bachelor Degree Project. English Linguistics. Supervisor: Jan Pedersen.

- Nathalie, Ramiere (2006). "Reaching a Foreign Audience: Cultural Transfers in Audiovisual Translation", in: The Journal of Specialized Translation. Issue 6 - July. 
- Nedergaard-Larsen, B. (1993). "Culture-bound problems in subtitling", in: Perspectives: Studies in Translatology, 1(2): 207-41.

- Neves, Josélia, "Languages Awareness through Training in Subtitling", in: Oerero Pilar (Ed.), in: Topics in audiovisual translation, John Benjamins Publishing Company 2004, 127-141.

- Newmark, P. (1988) A Textbook of Translation. New York and London PrenticeHall.

- Nida, E. (1964-2005). Toward a Science of Translating: With Special Reference to Principles and Procedures Involved in Bible Translating. Boston: Brill.

- Nida, E. (2001). Language and Culture-Contexts in Translation. Shanghai: Shanghai Foreign Language Education Press.

- Nobre, A. C. R. (2002). "Influência do Ambiente Audiovisual na Legendação de Filmes", in: Revista Brasileira de Linguística Aplicada.

- Nord, Ch. (2001). Translating as a Purposeful Activity - Functional Approaches Explained. Shanghai: Shanghai Foreign Language Education Press.

- Nowell-Smith, Geoffery (1997). The Oxford History of World Cinema. Oxford: Oxford University Press.

- O’Connell, E. (1996). "Media, Translation and Translation Studies”, in: T. Hickey \& J. Williams (Eds.). Language, Education and Society in a Changing World (pp. 151-6). Clevedon, England: Multilingual Matters.

- O'Connell, E. (2007). "Screen Translation", in P. Kuhiwczak \& K. Littau (Eds.). A Companion To Translation Studies (pp.120-133). Toronto: Multilingual Matters Ltd.

- Olk, H. M. (2001). The Translation of Cultural References: An Empirical Investigation into the Translation of Culture-Specific Lexis by Degree-Level Language Students. PhD thesis. Canterbury: University of Kent.

- Pedersen, Jan (2005), "How is culture rendered in subtitles?", in: MuTra Conference Proceedings, 18 p. [on line] http://www.euroconferences.info/proceedings/2005_Proceedings/2005_proceedings.htm 1

- Pedersen, Jan (2007). Scandinavian Subtitles. A Comparative Study of Subtitling Norms in Sweden and Denmark with a Focus on Extralinguistic Cultural References. Ph.D. Thesis, Stockholm University, Dept. of English.

- Pym, A. (1995). Venuti's Visibility. Anthony Pym review article of Lawrence Venuti's "The Translator's Invisibility: A History of Translation". London and New York: Routledge.

- Ritva, Leppihalme (1997). "Culture Bumps: An Empirical Approach to the Translation of Allusions", in: Multilingual Matters. Clevedon [U.K.] Philadelphia.

- Saiegh-Haddad, Elinor (2003). "Linguistic Distance and Initial Reading Acquisition": The Case of Arabic Diglossia", in: Applied Psycholinguistics 24.431-51. 39.

- Sapir, E. (1921). Language: An Introduction to the Study of Speech. New York: Harcourt, Brace and company.

- Schleiermacher, F. (1813). On the Different Methods of Translating. Berlin.

- Shafik, V. (1998-2007). Arab Cinema: History and Cultural Identity. The American University in Cairo Press; Revised edition.

- Smith, K., (2006). A Study of Brand Name Transfer from English Language to Russian Language Printed Advertisements, [on line] http://www.ingentaconnect.com/content/jbp/lic/200. [Assessed = November 12, 2008]. 
- Sperber D. \& Wilson D. (1986). Relevance: Communication and Cognition. Oxford: Blackwell.

- Sponholz, Ch. (2003). Teaching Audiovisual Translation Theoretical Aspects, Market Requirements, University Training and Curriculum Development. Unpublished thesis, [on line] http://isg.urv.es/library/papers/thesis_Christine_Sponholz.doc.

- Szarkowska A. (2005). "The Power of film Translation", in: Translation Journal, Vol.9, No. 2. Internet access: http://www.proz.com/doc/345.

- Tengku Mahadi, Tengku Sepora / Vaezian, Helia / Akbari, Mahmoud (2010).

Corpora in Translation: A Practical Guide. Oxford: Peter Lang Bern.

- Tewfic, S. (1965). "Hollywood on the Nile", in Saudi Aramco World, Vol. 16.

- Thawabteh, Mohammad Ahmad (2010). "The Translatability of Euphemism and Dysphemism in Arabic-English Subtitling", in: Lexis 7: Euphemism as a WordFormation Process.

- Thawabteh, Mohammad Ahmad (2011). "Lexical Problems in Arabic-English Subtitling”, in: UDC 81 25:791 kultura [online]: Godina II, broj 2, 2011. 207.

- Tian, Chuanmao. 2013. "Toward an RT-Based Functionalist Approach to Subtitling: A Case Study", in: International Journal of English and Literature, 2: 33-39.

- Tomaszkiewicz, T. (2001). "Transfert des références culturelles dans les sous-titres filmiques", in: Gambier, Y. and H. Gottlieb (Eds.). Multi Media Translation: Concepts, Practices, and Research. Amsterdam and Philadelphia: John Benjamins, 237-247.

- Venuti, Lawrence (1995). The Translator's Invisibility. London/New York: Routledge.

- Venuti, Lawrence (1998b). The Scandals of Translation. Towards an Ethics of Difference. London \& New York: Routledge.

- Vermeer, H. (1989a). Skopos and translation Commission. Heidelberg: Universitat.

- Vermes, Albert Péter 2003. "Proper Names in Translation: An Explanatory Attempt", in: Across Languages and Cultures 4 (1), pp. 89-108. Budapest: Akadémiai Kiadó.

- Vinay, J.P. and J. Darbelnet (1977). Stylistique Comparée Du Français et De l'anglais Paris: Didier. In English as (1995). Comparative Stylistics of French and English, translated by J. C. Sager and M. J. Hamel, Amsterdam and Philadelphia: John Benjamins

- Warschauer, M, Ghada R., Ayman Z. (2002). "Language Choice Online: Globalization and Identity in Egypt". JCMC, Vol. 7:4, 1-18. [on line] (http:www.ascuse.org/jcmc/vol7/issue4/sheffer.html)

- Wenfen, Y. (2010). "Brief Study on Domestication and Foreignization in Translation", in: Journal of Language Teaching and Research, Vol. 1, No. 1, pp. 77-80.

- Wiersema, N., (2004). "Globalization And Translation: A Discussion of the Effect of Globalization on Today's Translation", in: Translation Journal, vol. 8, No. 1.

- Zanettin, F., Bernardini, S. \& Stewart, D (Eds) (2003). Corpora in Translator

Education. Manchester: St Jerome Publishing. 
أمركة ترجمة الافلام : دراسة لغوية- اجتماعية لترجمة الافلام في العالم العربي

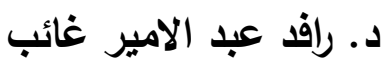

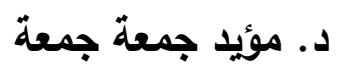

كلية المأمون الجامعة/ قسم الترجمة كلية المأمون الجامعة/ قسم اللغة الانكليزية

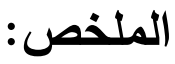
اوجد التوسع الهائل في وسائل الاعلام الذي يشهده عالمنا المعاصر تحديا كبيرا لعملية الترجمة في انحاء

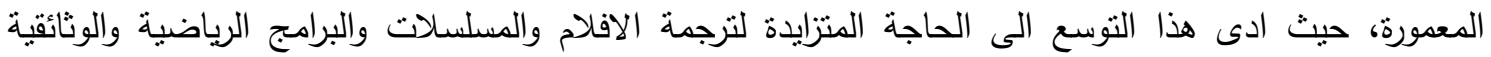

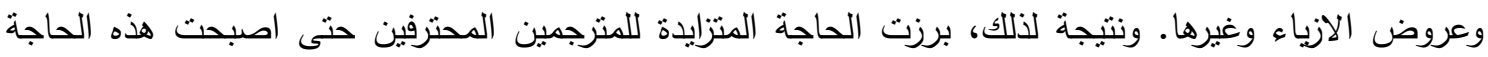

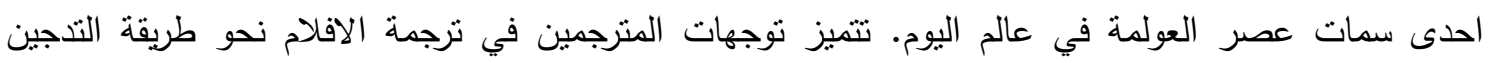

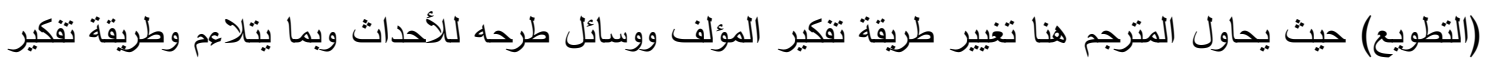

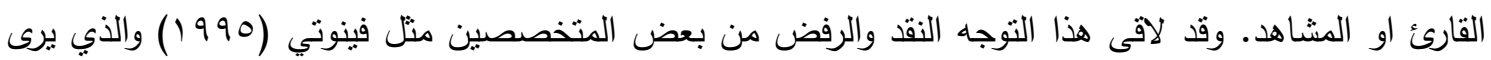

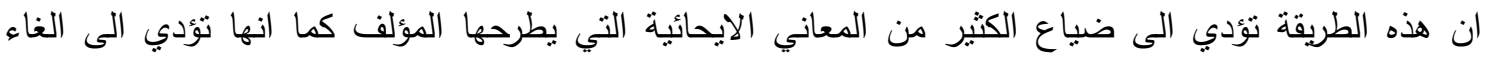

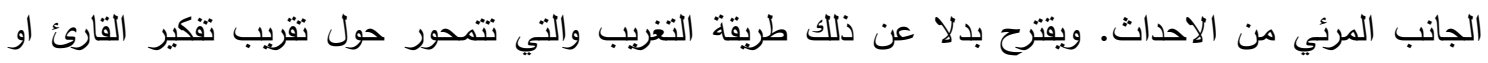

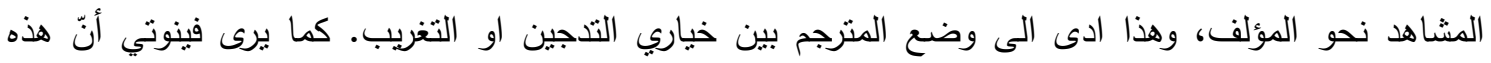

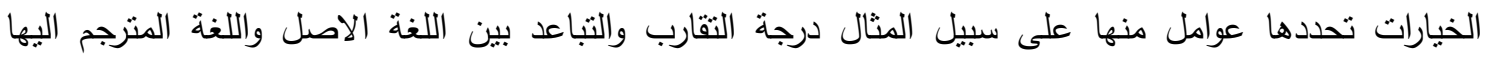
وموضوعة النص وامكانية المترجم ومعرفته بمختلف الجوانب الاجتماعية والثقافية في اللغتين الخ. يهذف البحث الحالي الى تسليط الضوء على ترجمة الافلام الامريكية في العالم العربي في ضوء ثنائية فينوتي في

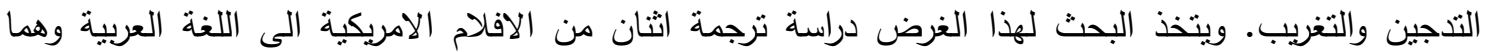
(الملاح) و (الراحل) وترجمة فيلم (حسن ومرقص) من اللغة العربية للإنكليزية. الكلمات المفتاحية: ترجمة الافلام، التشجين، التغريب، فينوتي، العربية. 